\title{
POWER RELATIONSHIP MARKETING DALAM BISNIS
}

\author{
Ali Hasan \\ NIDN 0007106001 , \\ email : ali43ibc@gmail.com \\ Dosen Marketing Sekolah Tinggi Pariwisata AMPTA Yogyakarta
}

\begin{abstract}
Understanding the motivations of consumers to engage in relationships with marketers is important for both practitioners and marketing scholars. To develop an effective theory of relationship marketing, it is necessary to under stand what motivates consumers to reduce their available market choices and engage in a relational market behavior by patronizing the same marketer in subsequent choice situations.

This article draws on established consumer behavior literature to suggest that consumers engage in relational marker behavior due to personal influences, social influences, and institutional influences. Consumers reduce their available choice and engage in relational market behavior because they want to simplify their buying and consuming tasks, simplile information processing, reduce perceimd risky, and maintain convetitive consistency and a state of psychological comfort. The willingness and ability of both consumers and marketers to engage in relational marketing will lead to greater marketing productivity; unless either consumers or mar keters abuse the mutual interdependence and cooperation.

This article examines theoretical contributions to a comprehensive relationship marketing concept. In the modern of marketing sciences, that interaction in networks of relat ionships constitutes both the essence of life itself and the essence of society. Marketing just applying the perspective of its own discipline and not properly considering the context within which marketing operates. The article offers an overview of the contributions to relationship marketing from traditional consumer goods marketing, services marketing, business marketing and base theory for research.
\end{abstract}

Key word : power of relationship marketing, service and goods marketing, and customer profitability.

\section{PENDAHULUAN}

Dalam lingkungan bisnis yang semakin hyperkompetitif, retensi, loyalitas dan profitabilitas merupakan kunci bagi pertumbuhan dan keberhasilan industri apapun. Banyak perusahaan kini menyadari peran relationship marketing (RM) dalam meretensi dan menciptakan asosiasi dengan sepanjang umur hidup pelanggan walaupun dalam jumlah kecil jauh lebih menguntungkan dan memiliki dampak besar pada perusahaan, mengurangi biaya pemasaran sekaligus memberikan keunggulan kompetitif.

Dalam rangka menciptakan nilai, mempertahankan pelanggan dan mendorong pembelian ulang, RM berkembang di seluruh area perusahaan. Hubungan baik (silaturahmi - dalam Agama Islam) dengan pemasok, distributor, pesaing dan karyawan melalui penggunaan RM dieksekusi untuk menciptakan nilai bagi pelanggan di semua operasi perusahaan untuk (1) merespon permintaan pelanggan dan penyediaannya disesuaikan dengan pengalaman pelanggan secara interaktif, (2) untuk mengakuisisi, dan mempertahankan hubungan jangka panjang dengan pelanggan, (3) mengeksplorasi biaya layanan (lebih efisien) dan menawarkan kualitas layanan yang lebih baik dari pesaing.

Semua sepakat, dalam bisnis, bahwa merek tidak memiliki siklus hidup, pabrik dapat saja terbakar, mesinmesin bisa habis dipakai, dan pendirinya juga mati, sementara merek dapat hidup selamanya. Sebuah merek dapat tumbuh dengan nilai tertentu dari waktu ke waktu, mungkin juga mirip loyalitas produk. Retensi dan loyalitas merek adalah fondasi untuk bertahan, partumbuhan yang menguntungkan. Sayangnya, ketika merek mati, atau loyalitas dan profitabilitas merek menurun, sering tidak disadari bahwa merek itu mati karena dibunuh oleh praktek pemasaran yang sesat, dan penurunan loyalitas merek karena dilukai oleh tindakan pemasaran yang salah.

Kemampuan perusahaan memadukan pemasaran ofensif eksternal, pemasaran defensif internal dan pemasaran interaktif muncul menjadi kekuatan Relationship Marketing dalam mengikat hubungan pelanggan dengan perusahaan. Pemasaran ofensif eksternal - mengambarkan arah kegiatan eksternal untuk mendapatkan pelanggan baru, meningkatkan frekuensi pembelian pelanggan, berfokus pada upaya membebaskan pelanggan yang tidak puas dari pesaing dan menghasilkan pelanggan baru. Pemasaran defensif internal (memilih, melatih, dan memotivasi karyawan) agar dapat memberikan pelayanan yang terbaik kepada pelanggan, membuat upaya-upaya retensi, meningkatkan hambatan beralih, mengelola ketidakpuasan pelanggan dan meningkatkan loyalitas pelanggan. Pemasaran interaktif adalah pengembangan kolaborasi semua aktivitas bisnis, memilih dan menggunakan strategi relasional yang dapat memberikan respon terhadap perbaikan internal kedalam fungsi ekternal perusahaan. 
Kemampuan untuk bertahan, dan pertumbuhan yang menguntungkan dalam rentang waktu itulah sebetulnya fokus RM. Loyalitas merek adalah dasar untuk bertahan dan pertumbuhan yang menguntungkan, misalnya loyalitas merek meninggkat, sensitivitas harga turu, biaya pemasaran turun, sensitivitas terhadap ransangan promosi pesaing turun. Komitmen yang tak pernah berakhir dari penggunaan RM adalah memenangkan dan menjaga loyalitas pelanggan terhadap merek harus diawali dengan pemahaman yang memadai tentang konsep dasar, driver nilai, power, pengembangan, kerangka kerja, membangun hubungan dan merubah pelanggan baru menjadi pelanggan ulang yang tidak terjadi begitu saja, oleh karena itu implementasi relationship marketing harus dilakukan secara benar sebagai bagian penting bagi marketer untuk menciptakan loyalitas pelanggan.

\section{KONSEP DASARRELATIONSHIP MARKETING}

RM bukan konsep untuk menggantikan konsep pemasaran yang sudah ada, Transaksional Marketing (TM) misalnya (tabel 1) berpusat pada bauran pemasaran (4P), yang digambarkan sebagai "panduan sempurna dalam perencanaan dan eksekusi strategi pemasaran".

Tabel 1. Perbedaan Konsep TM dan RM

\begin{tabular}{|c|c|c|c|}
\hline \multicolumn{2}{|r|}{ Dimensi } & TM & RM \\
\hline 1 & Waktu & fokus jangka pendek & fokus jangka panjang \\
\hline 2 & Elastisitas Harga & sensitif terhadap harga & kurang sensitif terhadap harga \\
\hline 3 & Kualitas & kualitas output (kualitas teknis) & kualitas interaksi - kualitas fungsional \\
\hline 4 & Kepuasan & $\begin{array}{l}\text { pemantauan pangsa pasar } \\
\text { (pendekatan tidak langsung) }\end{array}$ & $\begin{array}{l}\text { mengelola basis pelanggan } \\
\text { (pendekatan langsung) }\end{array}$ \\
\hline 5 & Sistem Informasi Pelanggan & ad hoc, survei pelanggan & real-time, sistem umpan balik pelanggan \\
\hline 6 & Operasional Marketing & $\begin{array}{l}\text { kepentingan strategis tidak } \\
\text { ada atau terbatas }\end{array}$ & $\begin{array}{l}\text { kepentingan strategis untuk } \\
\text { sukses sangat besar }\end{array}$ \\
\hline 7 & Peran Pemasaran internal & $\begin{array}{l}\text { tidak ada atau terbatas } \\
\text { penting untuk sukses }\end{array}$ & $\begin{array}{l}\text { substansi strategis penting } \\
\text { untuk keberhasilan }\end{array}$ \\
\hline 8 & Komitmen thd pelanggan & Kurang & Tinggi \\
\hline 9 & Produk & Produk barang & Produk dan jasa \\
\hline 10 & Selling & Face to face selling & Melibatkan tingkat hubungan \\
\hline 11 & Kualitas & $\begin{array}{l}\text { tanggung jawab departemen } \\
\text { produksi }\end{array}$ & $\begin{array}{l}\text { Tanggung jawab semua } \\
\text { departemen }\end{array}$ \\
\hline
\end{tabular}

RM sebagai konsep mengakui nilai hubungan jangka panjang pelanggan dan memperluas komunikasi melampaui iklan dan pesan promosi. Memadukan keduanya justru akan menjadikan upaya pemasaran menjadi semakin tajam, jelas dan komprehensip dalam : (1) mendeteksi mana pelanggan yang mengkhianati dan mana yang setia kepada merek, (2) membangun komunikasi dua arah yang terus menerus, terbuka, konstruktif dan umpan balik dari pelanggan (lama maupun baru).

Konsep dasar relationship marketing is a strategic process aiming to establish, develop, maintain and strengthen the relationships and the achievement of common objectives. 1 Definisi ini menunjuk pada pengaturan jaringan hubungan di mana pelanggan dan perusahaan memiliki kepentingan untuk mencapai tujuan yang sama yaitu pertukaran yang lebih memuaskan, lebih bermakna, lebih holistik dan pribadional, dan menciptakan pengalaman untuk mendorong hubungan yang lebih kuat. Sementara itu, konsep marketing yang memiliki dimensi jangka panjang dirumus-kan sebagai establish long-term customer relationship, develop long-term customer relationship, maintain long-term customer relationship, dan commercialice long-term customer relationship. 2 Basisnya adalah nilai produk dan kualitas layanan yang lebih kompetitif bagi pelanggan secara berkelanjutan dibanding pesaing. Sejumlah ide dasar RM adalah sebagai berikut :

1. RM merupakan aktivitas pemasaran yang dibangun atas empat filar utama yaitu mengidentifikasi (identify), menarik (attract), mempertahankan (depend), dan memperkuat (strengthen) loyalitas merek, atau memperkuat hubungan untuk mencapai tujuan yang saling menguntungkan;

2. RM sebagai bentuk pemasaran yang dikembangkan dari stimulus pemasaran langsung yang menekankan pada retensi pelanggan, kepuasan dan loyalitas terhadap tawaran perusahaan.

3. RM merupakan strategi proaktif yang dirancang untuk membangun dan menciptakan basis ekuitas relasional pelanggan dan saluran yang dapat menghasilkan peningkatan retensi pelanggan;

4. RM merupakam proses memodifikasi perilaku pelanggan dari waktu ke waktu dan belajar dari setiap interaksi untuk memperkuat ikatan pelanggan dengan perusahaan. ${ }^{3}$ 
Jika perusahaan mampu - berhasil mengidentifikasi, memelihara, dan mengembangkan hubungan pertukaran, perusahaan dapat meningkatkan kinerja bisnis, mampu mengurangi biaya, meningkatkan kepuasan, memperkuat loyalitas dan meningkatkan value bagi perusahaan. ${ }^{4}$

Variasi substitusi dan produk baru terus bertambah sesuai perkembangan kemampuan rekayasa manusia mendorong peningkatan ragam tawaran bagi pelanggan, maka kebutuhan menggunakan RM untuk retensi dan loyalitas pelanggan adalah sama pentingnya dengan menarik dan mengakuisisi pelanggan. Perubahan orientasi dari TM menjadi RM memerlukan berbagai pemahaman sebagai berikut :

1. RM mengintegrasikan informasi dari semua sumber data di dalam perusahaan untuk memberikan pandangan menyeluruh dari setiap pelanggan secara real time. Hal ini memungkinkan kolaborasi antar devisi dalam perusahaan dapat membuat keputusan yang cepat untuk melakukan crossselling, dan posisi kompetitif untuk membantu perusahaan memperkuat hubungan dengan pelanggan dalam berbagai cara dan bentuk, di berbagai industri yang berbeda.

2. Usaha memperlakukan hubungan pelanggan sebagai sumber daya bisnis yang bernilai harus dikelola, dipelihara, dan didukung oleh sistem informasi. Demikian juga, para pelanggan mengharapkan layanan profesional dan dukungan dengan setiap interaksi, melalui saluran mana pun, dari mana saja di dunia ini. Harapan atas layanan berkualitas tinggi atas ledakan pilihan barang dan jasa semakin diperlukan.

3. Pergeseran keseimbangan kekuatan pemasok kepada pelanggan. Globalisasi memperluas pilihan pelanggan di seluruh negara. Media e-marketing dapat membantu konsumen mengevaluasi keberagam pilihan untuk dibeli, dan disaat yang sama ekuitas relasional lemah, ketidakpuasan terhadap perusahaan (keuangan, kartu kredit, travel agent - pemandu wisata atau lainnya), pelang-gan akan dapat dengan mudah beralih ke perusahaan lain.

4. Sementara itu kualitas layanan pelanggan adalah faktor penting bagi sukses dan keunggulan kompetitif perusahaan, pekerjaan rancang bangun hubungan dengan pelanggan berkembang jauh lebih kompleks untuk sebagian besar perusahaan. Oleh karena itu aplikasi RM dengan media social marketing memungkinkan perusahaan menjadi lebih baik dalam mengelola hubungan pelanggan yang sangat berharga itu.

5. Semua sumber daya bisnis seperti customer, financial, physical facilities, employee, supplier, pengetahuan, relational serta perusahaan menjadi penggerak dan penentu arah penciptaan value bisnis yang menguntungkan: "the true relationshi of every company is to make customers, keep customers and maximize customer profitability" setiap hubungan pemasaran yang benar akan memaksimalkan profitabilitas pelanggan, perusahaan bisa hidup sekarang maupun yang akan datang.

RM sebagai suatu proses sifatnya sangat fleksibel antar divisi mampu membentuk gerakan efisiensi dengan mengintegrasikan 11 prinsip utama berikut:

1. Nilai produk, fokus pada produk yang paling bernilai berdasarkan pandangan pelanggan bukan dari pandangan perusahaan terhadap produk yang ingin dijual, banyak kegagalan program loyalitas terjadi karena salah memahami manfaat yang ingin diperoleh pelanggan.

2. Nilai Segmentasi: segmentasi berbasis kebutuhan pelanggan, preferensi, perilaku dan potensi ekonomi, yang menyediakan dasar untuk keputusan alokasi sumber daya di bidang pemasaran, penjualan dan pelayanan. mampu memahami kepentingan nilai relatif dari setiap segmen pelanggan dan kemampuan menentukan value untuk mempengaruhi laba secara positif. Kemampuan ini sangat dipengaruhi seberapa jauh marketer mampu menyusun kriteria seleksi pelanggan, efesiensi dalam akuisisi pelanggan, membuat pelanggan dapat bertahan dalam jangka panjang5 dan meningkatkan loyalitas pelanggan untuk meraih customer wallet share dapat di model seperti dalam gambar 1 .

3. Nilai Kelembagaan: ketika pelanggan berinteraksi dengan perusahaan, setiap orang akan menyadari tindakan sebelumnya, isu-isu sukses yang beredar dan peluang yang tertunda serta ukuran nilai kelembagaan yang dicapai secara akurat dengan tolak ukur ROI (return on investment).

4. Kolaborasi: pelanggan yang terlibat dalam proses desain, spesifikasi dan / atau pengiriman hasil yang diinginkan, memberikan perlakuan khusus secara induvidual (sikap, kebiasaan, gaya,) mereka senang dikelola (dirubah dan dipertahankan) untuk jangka panjang,

5. Touch Point Alignment: pelanggan dapat melakukan bisnis dengan perusahaan melalui berbagai saluran yang sesuai dengan kebutuhannya, dan karenanya perusahaan harus mampu mengidentifikasi nilai yang paling tepat untuk ditawarkan kepada pelanggan, mengkomuni-kasikan dan menyampaikan nilai yang paling diinginkan oleh setiap segmen-pelanggan

6. Satu \& Selesai: kebutuhan konsumen diselesaikan pada kontak pertama, membiarkan antrian panjang untuk memperoleh layanan akan menimbulkan kesan negatif. 


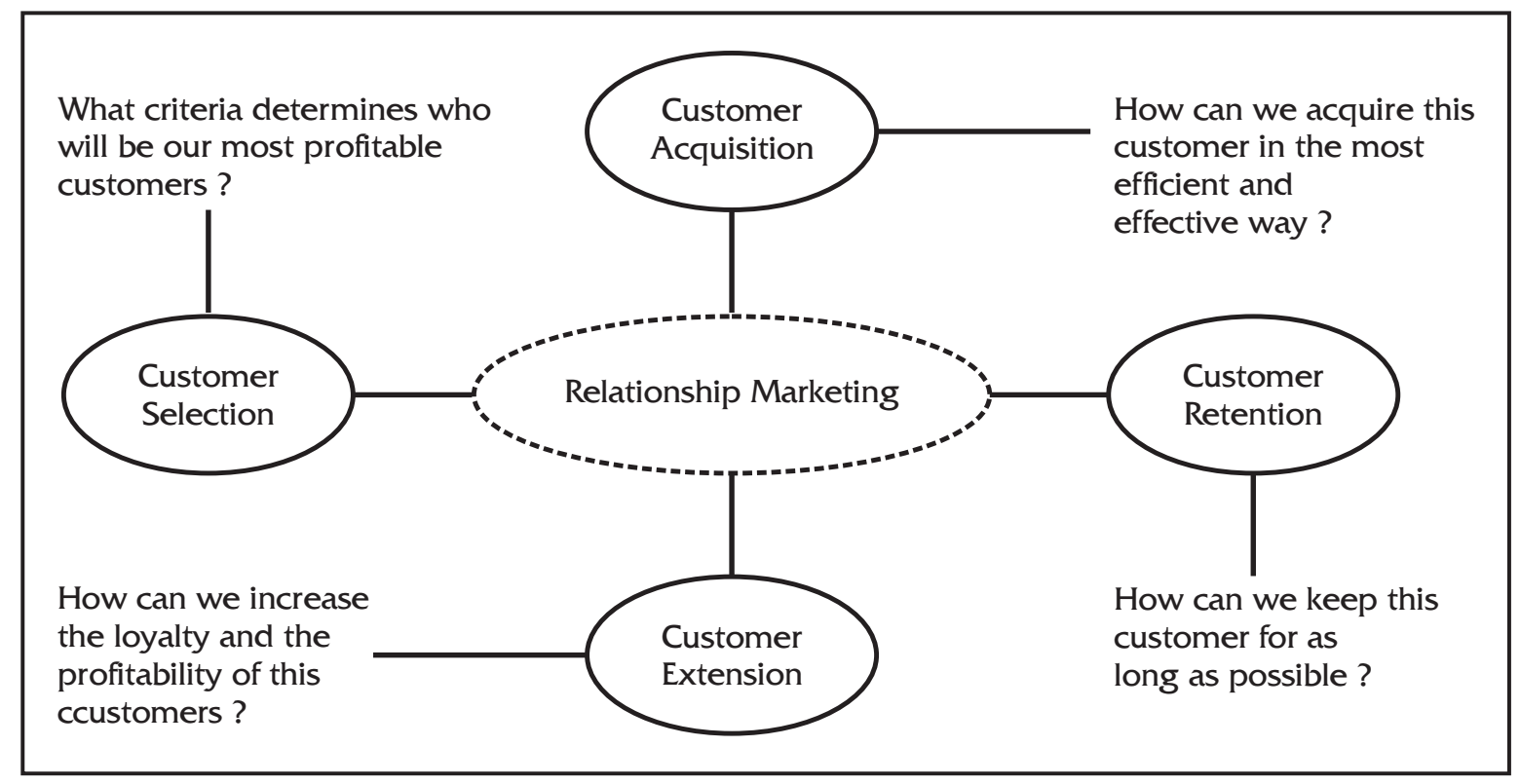

Gambar 1. Model Relationship Marketing

7. Informasi real time: para karyawan memiliki akses real-time ke informasi yang tepat untuk membuat keputusan untuk mengatasi masalah berbasis pelanggan dengan segera.

8. Scorecard pelanggan: persyaratan kinerja karyawan dan langkah-langkah yang dirancang untuk mengarahkan perilaku pelanggan diukur secara eksplisit.

9. Proses closed and loop: keterpaduan sistem untuk memastikan bahwa informasi dan alur kerja seluruh unit perusahaan berlangsung secara logis, menutup loop pelanggan dan memungkinkan memperbaiki pengetahuan secara terus menerus.

10. Mendengarkan and Belajar: forum ini memfasilitasi berbagi informasi dan belajar di antara para pelanggan yang membantu mereka melakukan bisnis dengan perusahaan.

11. Customer Experience: setelah semua "titik sentuh" di atas telah dipetakan, perusahaan mampu memberikan kualitas, konsistensi dalam memberikan nilai tambah bagi pengalaman pelanggan. RM bukan design unit pengobatan gawat darurat dalam mengatasi perusahaan yang sakit (kesulitan), tetapi pengo-batan untuk kesehatan perusahaan jangka panjang (laba).

\section{POWER RELATIONSHIP MARKETINC}

Diakui, bahwa merekrut pelanggan baru adalah bagian penting dari keberhasilan perusahaan manapun (baik barang maupun jasa) layanan, semua perusahaan mengalokasikan jumlah yang sangat besar waktu dan uang untuk menarik pelanggan potensial dan mengkonversinya menjadi pelanggan yang sebenarnya. Demografi, geografi, psikografi dan prilaku konsumen dipelajari, peluang dan target diidentifikasi dan dianalisis, alokasi sumber daya yang berharga dikerahkan untuk memenangkan pelanggan baru. Secara khusus aplikabilitas RM ini memiliki power sebagai berikut :

Pertama, dengan menyediakan layanan yang disesuaikan untuk menciptakan keterikatan dan biaya switching yang lebih tinggi, misalnya: biaya pencarian, biaya mempelajari produk, biaya emosional dan faktor risiko terkait dengan perubahan mitra bisnis atau setidaknya menciptakan cross-selling.

Kedua, sensitivitas pelanggan terhadap harga berkurang, hambatan kompetitor untuk masuk, pengeluaran pemasaran yang lebih rendah, stabilitas meningkat dan ketidakpastian menurun, mempertahankan jumlah pembelian dan penurunan biaya operasi pelanggan. Contoh logisnya adalah ketika kunjungan awal ke agen (motor, mobil atau lainnya), konsumen diminta dan dibantu mengisi formulir lengkap, sekali informasi ini tersedia sesuai kebutuhan klien dan kebutuhan informasi tambahan menjadi kurang pada setiap pertemuan layanan berikutnya, akan mengurangi biaya operasi bagi perusahaan.

Ketiga, perusahaan memperoleh pengalaman dengan pelanggan, dapat melayani mereka lebih efisien. Contoh ini dapat dilihat dalam industri perbankan, frekuensi pelanggan datang, apa yang diharapkan dari bank, masalah dan mengajukan pertanyaan lebih sedikit. Akibatnya, perusahaan menjadi lebih efisien karena mereka menjadi akrab dengan situasi keuangan dan preferensi pelanggan.

Keempat, mempertahankan perusahaan dengan pelanggan jangka panjang kadang-kadang mendapat manfaat nilai lebih dari pelanggan. Dalam industri medis misalnya, di mana klien mungkin bersedia membayar lebih untuk dokter mereka daripada risiko mengunjungi dokter lain yang lebih murah. Layanan perusahaan, yang 
telah berkembang dengan pelanggan setia, dan premi kepercayaan pelanggan dalam bisnis dan kepentingan relatif dari efek akhir dari pelanggan jangka panjang adalah menghasilkan keuntungan yang semakin meningkat.

Kelima, pengurangan jumlah pembelotan pelanggan secara signifikan dapat meningkatkan keun-tungan bottom line, lebih dari akuisisi pelanggan baru. Hubungan jangka panjang akan menghemat biaya pendidikan dan pelatihan dan efek pengalaman akan meningkatkan pengelolaan kualitas dalam berbagai aspek. Biaya dalam menghasilkan bisnis baru lebih tinggi, seperti penelitian, prospeksi, pertemuan, proposal dan pengembangan. Biaya dapat terwujud dalam berbagai cara seperti iklan dan direct mail pada konsumen yang ditargetkan; biaya tenaga penjualan dan keterlibatan sosial yang diperlukan seperti jamuan makan malam. Biaya administrasi tersembunyi seperti pemeriksaan kredit, membuka rekening baru, membuat dan revisi kontrak, biaya pencarian dan biaya startup akan menambah harga untuk mendapatkan pelanggan baru, sering berurusan dengan konsumen baru.

Keenam, mengurangi biaya pemasaran dan kompleksitas operasional - reduksi biaya pemasaran menjadi dorongan penggunaan relasi dengan pelanggan dan peningkatan keuntungan yang dramatis dari peningkatan kecil pada retensi pelanggan. RM dengan bantuan penggunaan EFT dalam retail customer service - dapat membangun dan memelihara hubungan dengan pelanggan dalam biaya yang lebih ringan dan kompleksitas dapat diatasi dengan infrastruktur yang fleksibel dan keberhasilan agregat dengan ukuran yang berbeda. Kinerja bisnsis yang mampu memberikan berbagai macam integrasi, tim, tools perusa-haan dan produk yang mendukung wawasan perusahaan untuk membantu perusahaan membuat keputusan yang baik untuk mendorong produktivitas, dan kinerja bisnis secara keseluruhan.

1. Akuisisi, menunjukkan bahwa biaya akuisisi 5-10 kali lebih mahal dari biaya relasi untuk retensi, manfaat kumulatif dari lamanya siklus hubungan, kekuatan keuangan perusahaan semakin besar. Jika retensi pelanggan tinggi, perusahaan dapat dengan mudah mengirimkan penawaran baru. Keuntungan, mungkin negatif pada tahun pertama, oleh karena itu penting untuk menghitung nilai bersih perpelanggan. Jika perusahaan memperoleh kuantitas pelanggan yang menurun atau jika pelanggan yang kembali berkurang mengakibatkan biaya lebih tinggi dan pendapatan akan rendah, oleh karena itu perusahaan harus fokus pada pelanggan yang paling menguntungkan dan karenya praktik RM relatif akan berbeda. Secara kuantitatif return on relation untuk retensi : (1) pelanggan tetap 5,8\%, (2) pelanggan yang membeli ulang $9,5 \%$, dan (3) tingkat penurunan pelanggan $6,7 \%$ (tabel 2 ), 6 sementara itu ROI dari investasi iklan 27,3 persen ( $2 / 3$ anggaran iklan), promosi penjualan 18.1 persen ( $2 / 3$ anggaran promosi). Peningkatan $5 \%$ dalam retensi memiliki dampak $95 \%$ pada net present value, pelanggan tetap menghasilkan dua kali lebih banyak dari pendapatan kotor pelanggan baru. Pelanggan yang terlibat dalam proses menghasilkan pendapatan 1,7 kali lebih besar dari pelanggan biasa, sementara karyawan dan pelanggan yang terlibat dapat mengembalikan pendapatan 3 sampai 4 kali lebih besar. $^{7}$

Tabel 2. Dampak RM Terhadap Nilai Perusahaan

\begin{tabular}{|c|c|c|c|c|c|}
\hline Metrik & Dimensi & Definisi & base Value & $\begin{array}{l}\text { Jika Budget } \\
+10 \%\end{array}$ & Value \\
\hline \multirow[t]{2}{*}{$\begin{array}{l}\text { Menarik } \\
\text { Pelanggan }\end{array}$} & $\begin{array}{l}\text { biaya akuisisi } \\
\text { pelanggan }\end{array}$ & $\begin{array}{l}\text { biaya marketing } \\
\text { perpelanggan }\end{array}$ & $\$ 5.68$ & $\$ 5.11$ & $0.7 \%$ \\
\hline & $\begin{array}{l}\text { perubahan jumlah } \\
\text { pelanggan baru }\end{array}$ & $\begin{array}{l}\text { peningkatan jumlah } \\
\text { pelanggan baru }\end{array}$ & $62.4 \%$ & $72.4 \%$ & $3.1 \%$ \\
\hline \multirow{3}{*}{$\begin{array}{l}\text { Pelanggan } \\
\text { yang hilang }\end{array}$} & $\begin{array}{l}\text { biaya akuisisi } \\
\text { pelanggan baru }\end{array}$ & $\begin{array}{l}\text { biaya marketing } \\
\text { perpelanggan }\end{array}$ & $\$ 250$ & $\$ 225$ & $0.8 \%$ \\
\hline & $\begin{array}{l}\text { tingkat penurunan } \\
\text { pelanggan baru }\end{array}$ & $\begin{array}{l}\text { \% konsumen baru } \\
\text { menjadi pelanggan }\end{array}$ & $4.7 \%$ & $14.7 \%$ & $2.3 \%$ \\
\hline & $\begin{array}{l}\text { perubahan pendapatan } \\
\text { dari pelanggan baru }\end{array}$ & $\begin{array}{l}\text { peningkatan pendapatan } \\
\text { dari pelanggan baru }\end{array}$ & $88.5 \%$ & $98.5 \%$ & $4.6 \%$ \\
\hline \multirow{3}{*}{$\begin{array}{l}\text { Retensi } \\
\text { Pelanggan }\end{array}$} & $\begin{array}{l}\text { Pendapatan dari } \\
\text { pembeli ulang }\end{array}$ & $\begin{array}{l}\text { peningkatan pendapatan } \\
\text { dari pembeli ulang }\end{array}$ & $21.0 \%$ & $31.0 \%$ & $5.8 \%$ \\
\hline & $\begin{array}{l}\text { Penurunan pembeli } \\
\text { ulang }\end{array}$ & $\begin{array}{l}\text { \% pelanggan yang } \\
\text { melakukan pembelian ulang }\end{array}$ & $30.2 \%$ & $40.2 \%$ & $9.5 \%$ \\
\hline & $\begin{array}{l}\text { Jumlah pelanggan } \\
\text { yang hilang }\end{array}$ & $\%$ pembeli ulang & $55.3 \%$ & $65.3 \%$ & $6.7 \%$ \\
\hline
\end{tabular}


2. Pembeli, para pembeli terdiri dari pembeli yang paling menguntungkan, cukup menguntungkan dan tidak menguntungkan. Hasil riset ini menunjukan : Pertama, 4\% pembeli masuk dalam kelompok yang paling menguntungkan, mereka ini menyumbang $15 \%$ terhadap volume penjualan, tingkat keuntungan mencapai tiga kali dari titik impas. Kedua, $6 \%$ kelompok yang cukup menguntungkan menyumbang $9 \%$ terhadap volume penjualan. Ini berarti bahwa semua keuntungan berasal dari 10\% basis pelanggan. Ketiga, 65\% pembeli yang tidak mengun-tungkan, $51 \%$ sama sekali tidak menyumbang terhadap volume penjualan, return kelompok dari setiap rupiah yang dihabiskan untuk menjangkau pelanggan, $60 \%$ dari biaya pemasaran terbuang, 63\% promosi perdagangan dan 95\% iklan dan belanja media. Itu berarti bahwa dari anggaran pemasaran Rp 280.500.000.000, lebih dari Rp 170.000.000.000 terbuang sia-sia

3. Merek, ditemukan (a) $5,8 \%$ pengguna merek menyumbang $77,5 \%$ terhadap volume penjualan, (b) $9,8 \%$ pengguna merek menyumbang $75,1 \%$ terhadap volume penjualan, dan yang unik adalah (c) kurang dari $1 \%$ pengguna menyumbang 53,1\% terhadap volume penjualan.

4. Efek iklan pada rata-rata merek yang sukses terhadap penjualan, $30 \%$ berasal dari pelanggan baru, $70 \%$ berasal dari pelanggan yang loyal.

Ketujuh, memperkuat life time value, semakin lama seorang pelanggan sebagai advokasi dan partner perusahaan, semakin tinggi kemungkinan mereka akan terlibat dalam interaksi bisnis dengan perusahaan dan profitabilitas yang lebih besar dari waktu ke waktu.8 Dalam kontek inilah kemudian para akademisi dan praktisi menyoroti pentingnya nilai seumur hidup (life time value-LTV) dari pelanggan, yaitu, ukuran total kekayaan bersih perusahaan hubungannya dengan pelanggan setia. Konsep ini menjadi panduan penting dalam mengidentifikasi pelanggan yang paling sesuai dengan siapa perusahaan harus menjalin hubungan dan mengungkapkan berapa banyak pengeluaran perusahaan harus siap untuk berinvestasi dalam suatu hubungan. Ketika perusahaan berhasil membangun LTV, akan memberikan manfaat berikut ini :

1. Switching barrier, RM memungkinkan perusahaan untuk menawarkan layanan yang disesuaikan dengan pelanggan. Dengan demikian, biaya switching untuk pelanggan juga meningkat karena mereka mungkin merasa sulit untuk menyesuaikan diri dengan perusahaan lain yang tidak dapat menyesuaikan layanan segera.

2. Layanan pribadi, untuk layanan yang secara pribadi penting bagi konsumen atau layanan-layanan yang kompleks, pelanggan sering akan berusaha untuk memperpanjang keterikatannya kepada perusahaan. Medis, perbankan, asuransi, industri pariwisata atau lainnya yang sejenis melambangkan beberapa atau semua karakteristik yang akan menarik pelanggan untuk terus menggurui perusahaan. Pelanggan biasanya akan tetap setia kepada perusahaan ketika nilai yang mereka terima tidak dapat tergantikan oleh perusahaan lain yang sedang bersaing.

3. Percaya diri, hal ini berkaitan dengan perasaan keamanan dan kepercayaan pelanggan yang berkembang terhadap penjual. Emosi seperti mengurangi ambiguitas dan kecemasan dalam layanan yang ditawarkan dan karenanya, konsumen memilih untuk tidak mengubah penyedia layanan secara terus menerus. Pelanggan saat ini memiliki tuntutan waktu, sumber daya dan mencari cara untuk menyederhanakan pilihan mereka. RM memungkinkan pembeli untuk membebaskan mereka dari tuntutan itu, dan prioritas mereaka bisa untuk masalah lain.

4. Manfaat sosial, RM dibangun atas sifat manusia (konsumen) merasa dibutuhkan, sebagai pembeli mengembangkan rasa keakraban dengan penjual, menciptakan hubungan sosial dan pelanggan menjadi lebih loyal. Penata rambut, instruktur olahraga, dokter, bahkan manajer restoran (lokal), seringkali berfungsi sebagai sumber kepercayaan pribadi, dan membentuk sistem dukungan sosial bagi pelanggan yang akan terus berinvestasi dalam hubungan.

Kedelapan, memperkuat ketahanan pelangggan aktif, setelah diketahui kontribusi kelompok segmen aktif kepada perusahaan, perusahaan harus berupaya untuk memperkuat ketahanan pelanggan agar mereka tidak beralih ke perusahaan lain, dengan cara :

1. Membangun rintangan beralih yang tinggi.

Pelanggan umumnya enggan untuk beralih ke perusahaan lain, jika melibatkan biaya modal yang tinggi, biaya pencarian yang tinggi, kehilangan potongan harga dan sebagainya. Kajian empiris menunjukkan bahwa perusahaan yang mampu mengurangi peralihan pelanggan sekitar 5\% mampu meningkatkan laba perusahaan berkisar antara $25 \%$ sampai $85 \%$.

2. Memperbaiki kualitas layanan dan produk.

Cara yang lebih baik adalah, memberikan kepuasan yang tinggi kepada pelanggan lewat kualitas layanan, dan kualitas produk, serta fasilitas atau sarana pendukung lainnya secara signifikan akan mempersulit pesaing untuk meruntuhkan rintangan beralih dengan hanya mengandalkan tawaran keuntungan yang lebih tinggi atau perangsang lain untuk beralih. Kualitas layanan jelek, memboroskan waktu dan kekeliruan terjadi secara langsung menyebabkan beban biaya total semakin besar sebaliknya jika ingin mendapatkan beban biaya total yang paling rendah, maka perusahaan harus memastikan agar layanan bebas dari cacat, bebas boros waktu. 
3. Mengembangkan basis layanan individu.

one to one individual services dapat memperkuat posisioning perusahaan sebagai lambang privacy, increasing usage (program bagi hasil), augmenting product - services (memberi rasa bangga) dan extending the brand (nama kondang yang mengglobal).

Kesembilan, menghindari hambatan hubungan dengan pelanggan, sejumlah hambatan potensial dalam membangun hubungan dapat dihindari, dengan cara :

a. Mengembangkan hubungan personal (face to face personal - F2P). F2P ini bisa jadi sebagai rintangan ketika rasa percaya pelanggan terhadap orang/marketer/ perusa-haan hilang, sebaliknya F2P bisa menjadi elemen utama dalam mempertahankan pelanggan dan membangun loyalitas;

b. Transparansi dalam hubungan bisnis dapat menjadi masalah bagi perusahaan dengan harga yang tinggi pada posisi produk yang eksklusif. Tranparansi harus dapat menjadikan pelanggan sadar tentang faktafakta penting dari eksklusifitas itu bagi mereka, kalau ini gagal, akan membuat situasi perusahaan semakin sulit dan rumit;

c. Rancangan koneksi B2B dapat menjadi proses yang sangat kompleks karena membutuhkan sistem rantai pasokan yang otomatis, persediaan yang real time, kontrol perangkat lunak yang mudah, dll.

Kesepuluh, peningkatan pendapatan - usaha pemasaran yang komprehenship dapat membantu mencapai ROI yang lebih baik. Dengan rancangan informasi yang tersedia dari integrasi $R M$, perusahaan dapat meningkatkan siklus peluncuran produk, memberikan produk yang tepat, kepada pelanggan yang tepat, dan pada saat yang juga tepat

Dalam industri keuangan, aplikasi RM menyediakan informasi untuk meningkatkan pendapatan dan keuntungan perusahaan, dengan pelayanan EFT secara menyeluruh tanpa harus menyediakan upaya khusus dapat mendukung optimalisasi hubungan penjualan dan pelayanan pelanggan.

EFT dengan jaringan yang luas dapat membagi biaya dan resiko pengembangan produk baru, menurunkan biaya hantaran produk, meningkatkan nilai CLV dan mengatasi batasan geografis (nasional, internasional, global). Pembebanan tambahan biaya pada penggunaan teknologi umum-nya pelanggan menyatakan tidak keberatan dan biaya itu cukup fair - pantas. ${ }^{10}$

\section{PENGEMBANGAN RELATIONSHIP MARKETING}

RM muncul dari pergeseran iklim bisnis yang berorientasi pada hubungan jangka panjang dengan pelanggan, pesaing, dan pengaruh pasar lainnya. Dalam perspektif ini, pemasaran dihadapkan pada perilaku bisnis lewat internet yang benar-benar mendukung hubungan pemasaran, atau mungkin menghambat (bagi sebagian orang). Diakui, internet memang mendukung kegiatan pengembangan hubungan tetapi tidak mungkin dapat membuat kredibilitas, kepercayaan, komitmen dan kepuasan tanpa pemasaran offline.

Konsep transaksional marketing (produk, harga, promosi, dan tempat) dimana penjualan dan pembelian diarahkan mengikuti alur tindakan yang ditandai sebagai proses pertukaran independen yang menguntungkan. Sebaliknya, dalam RM tergantung pada kemampuan membangun hubungan jangka panjang dalam menggunakan pengaruh jaringan pasar untuk memahami dan mengantisipasi kebutuhan, mempertahankan pelanggan dengan cara memuaskan pelanggan (hanya pelanggan yang puas yang memiliki keinginan lebih tinggi untuk membeli kembali dibanding orang yang tidak puas).

Tujuan utama RM adalah untuk "membangun dan mempertahankan basis pelanggan yang menguntungkan dan berkomitmen untuk perusahaan" Tujuan ini dapat dicapai melalui retensi, akuisisi dan peningkatan hubungan sesuai urutan tangga RM11 (gambar 2). Tangga RM merupakan tahap pengembangan berbagai hubungan, membangun hubungan pelanggan yang memiliki relevansi untuk semua kelompok dalam domain pasar pelanggan. ${ }^{12}$

Langkah pertama untuk menciptakan partner (mitra) adalah mengidentifikasi suspek (suspect) dan prospek (prospect) untuk mengembangkan hubungan, marketer harus berusaha menggerakkan suspek dan prospek menaiki tangga menjadi first-time customers sebagai pembeli (purchaser) pertama kali.

Tahap selanjutnya adalah mengubah pembeli ini menjadi klien (orang yang telah menjadi basis pembeli ulang, namun sikapnya negatif atau mungkin netral). Ketika pelanggan mengakui adanya manfaat produk atau jasa, mereka akan melakukan pembelian ulang (repeat customers). Pelanggan yang terlibat dalam proses ini akan menjadi pendukung (supporter) dimana konsumen mulai menyukai perusahaan meskipun hanya pasif.

Seorang pelanggan yang berada pada tahap ini, akan tertarik untuk melanjutkan hubungan jika perusahaan memberikan penawaran kualitas dan nilai dari waktu ke waktu secara konsisten, pelanggan akan pindah ke tahap 'advokat' (advocate), pada tahap ini pelanggan bersedia menjadi marketer perusahaan, mempromosikan perusahan, pelanggan menjadi sangat bahagia dengan produk, mereka aktif menceritakan dan merekomendasikan kepada orang lain secara positif. Sikap pelanggan sangat positif dan tidak tertarik pada ransangan iklan pesaing dengan catatan bahwa perusahaan secara terus-menerus mampu mengembangkan kualitas produk dan layanan untuk memenuhi kebutuhan pelanggan.

Jika pada tahap advokat ini marketer berhasil mengembangkan hubungan yang memenuhi kebutuhan pelanggan, pelanggan akan 'merasa sebagai member' penting bagi pertumbuhan dan perluasan perusahaan. Apabila pada tahap member ini perusahaan 
dapat meningkatkan hubungan yang membantu konsumen setia bahkan lebih setia - membeli produk atau jasa selama hidupnya. Langkah terakhir dalam tangga RM adalah hubungan kemitraan (partner) yang berkembang lebih mendalam antara pelanggan dan perusahaan, tahap ini mampu menghasilkan hubungan yang saling percaya dan saling berbagi manfaat.

Keberhasilan RM dicirikan oleh kemampuan menciptakan hubungan yang lebih dekat/akrab dengan pasar, dengan cara menginstal kualitas hubungan, kepercayaan dan komitmen untuk menghasilkan keuntungan bagi semua pihak yang terlibat. Dengan mengurangi jarak, perusahaan mampu menyediakan nilai layanan yang lebih baik, perusahaan mampu mengumpulkan Informasi, yang kemudian digunakan untuk menciptakan hantaran nilai seumur hidup pelanggan dengan biaya yang lebih efisien, ini berarti perlu menjaga pelanggan agar mereka bersedia melakukan pembelian ulang. Oleh karena itu mengevaluasi setiap tahap hubungan terutama menilai kebutuhan investasi untuk membuat pelanggan menaiki tangga hubungan.

Investasi dalam RM diperioritaskan pada hubungan yang bermanfaat dalam hal nilai seumur hidup pelanggan. Evaluasi potensi pelanggan adalah proses penting serta mengelola biaya pada setiap tingkat dan unit bisnis dari perusahaan. Jika terjadi kesalahan dalam evaluasi potensi, perusahaan tidak harus ragu untuk memindahkan pelanggan pada tingkat layanan yang lebih rendah atau tidak memberi hubungan yang lebih mahal.

\section{DRIVER VALUE RELATIONSHIP MARKETING}

Nilai-nilai fungsional hubungan dengan pelanggan akan menjadi kuat jika didorong oleh kualitas hubungan, kepercayaan dan komitment. ${ }^{13}$

\section{Relationship quality}

Kualitas hubungan terbentuk dari hasil interaksi dari waktu ke waktu dan ketika mutunya meningkat, hubungan menjadi semakin dekat. Pentingnya mutu hubungan (relationship quality - RQ) dimaknai "sebagai derajat kepantasan suatu hubungan untuk memenuhi kebutuhan pelanggan". ${ }^{14}$ Konsep RQ dijelaskan oleh persepsi pelanggan atas keinginan dan kebutuhan mereka terpenuhi oleh penyedia. Jika nilai RQ tinggi, maka

a. pertukaran itu memuaskan, artinya hubungan itu sukses, RQ menjadi lem (perekat) yang kuat untuk menjaga para pembeli - para penjual dan bersamasama mengubah bentuk transaksi terpisah ke dalam bentuk partnerships.

b. dapat memanage dan mengurangi kecenderungan pelanggan meninggalkan hubungan pembelian. umur hubungan yang panjang mempengaruhi profitabilitas, kesediaan membayar dengan harga lebih tinggi dibanding pesaing, mempengaruhi tingkat pendapatan dan rekomendasi produk - jasa kepada orang yang lain dari mulut ke mulut secara positif. $^{15}$

\section{Kepercayaan}

Kepercayaan, adalah kemampuan untuk memprediksi tindakan pelanggan dalam hubungan dan kepercayaan. Kepercayaan merupakan fondasi penting dalam membangun hubungan. Kepercayaan dibentuk oleh kemampuan memelihara janji, dan peningkatan RQ. Kepercayaan terhadap mitra pertukaran baik baik dalam konteks B2B maupun B2C, pelanggan berusaha mengurangi resiko dari pilihan penyedia/penyalur yang dipercaya oleh pelanggan. Dalam industri, ketika pembeli dapat mengenali $R Q$, maka kepercayaan dan kepuasan terhadap penyedia produk, pelanggan akan bergerak ke arah perilaku positif. Berbagai kajian empiris menunjukan bahwa kepercayaan mempunyai dampak lebih kuat terhadap pembelian ulang dan rekomendasi dari mulut ke mulut positif dibanding kepuasan. Kepercayaan pelanggan menjadi prasyarat dalam mutu hubungan dan hubungan jangka panjang yang sukses. $^{16}$

3. Komitmen

Komitmen, dianggap sebagai hasil dari hubungan yang baik. Komitmen didefinisikan sebagai keinginan untuk mengembangkan hubungan yang stabil, kemauan membuat pengorbanan jangka pendek untuk menjaga hubungan jangka panjang dan stabilitas kepercayaan dalam hubungan jangka panjang. Kepercayaan terhadap hubungan adalah komitmen yang sangat berharga bagi perusahaan. Kepercayaan menjadi faktor kunci dalam mengarahkan komitmen pelanggan pada perusahaan, oleh karena itu ketika hubungan yang telah terbentuk itu kuat, pelanggan tidak akan beralih ke nilai yang ditawarkan oleh perusahaan lain, demikian juga ketika komitmen yang dihasilkan lebih tinggi, maka hubungan itu menjadi lebih kuat, sebaliknya lemahnya komitmen, kepercayaan akan rontok, dan hubungan akan bubar. Pada saat RM dan RQ dijadikan tujuan, maka kepercayaan, dan komitmen menjadi titik awal dalam komunikasi lanjutan. Kepercayaan pelanggan terhadap perusahaan pada hakekatnya adalah hasil superior uang dapat dicapai ketika ukuran bangunan kepercayaan dirancang untuk menanamkan kesediaan pelanggan untuk merekomendasikan perusahaan kepada orang lain (keluarga, teman, rekan kerja).

Gambar 3 menunjukkan empat cara dalam mengelola nilai hubungan dengan pelanggan : manajemen portofolio pelanggan, set-up posisi nilai, peran nilai tambah, hadiah dan pembagian risiko. $^{17}$ 
1. Manajemen Portofolio Pelanggan

Manajemen portofolio pelanggan berarti bahwa bagaimana pilihan hubungan pelanggan yang berharga dari prinsip-prinsip manajemen pada : (1) Tingkat Pasar, perusahaan perlu membuat target portofolio pelanggan yang memeliki daya-beli terbaik, (2) Tingkat grup, perusahaan perlu membuat kepastian yang dapat membedakan kelompok jenis pelanggan, kelompok pelanggan ini dapat memberikan umpan balik perusahaan. Manajer menyediakan layanan yang memenuhi kebutuhan khusus "pelanggan". (3) Tingkat Individu, marketer perlu mengeksplorasi penge-tahuan pelanggan lebih mendalam dan mengadopsi manajemen individu ketika kebutuhan sangat berbeda dalam nilai relasi, preferensi, dan kebutuhan individu. ${ }^{18}$

\section{Set-up Posisi Nilai}

Posisi nilai yang berarti bahwa tingkat pertukaran nilai antara pembeli dan penjual. Bisnis akan memberikan layanan yang lebih dalam rantai nilai atau pengalaman total

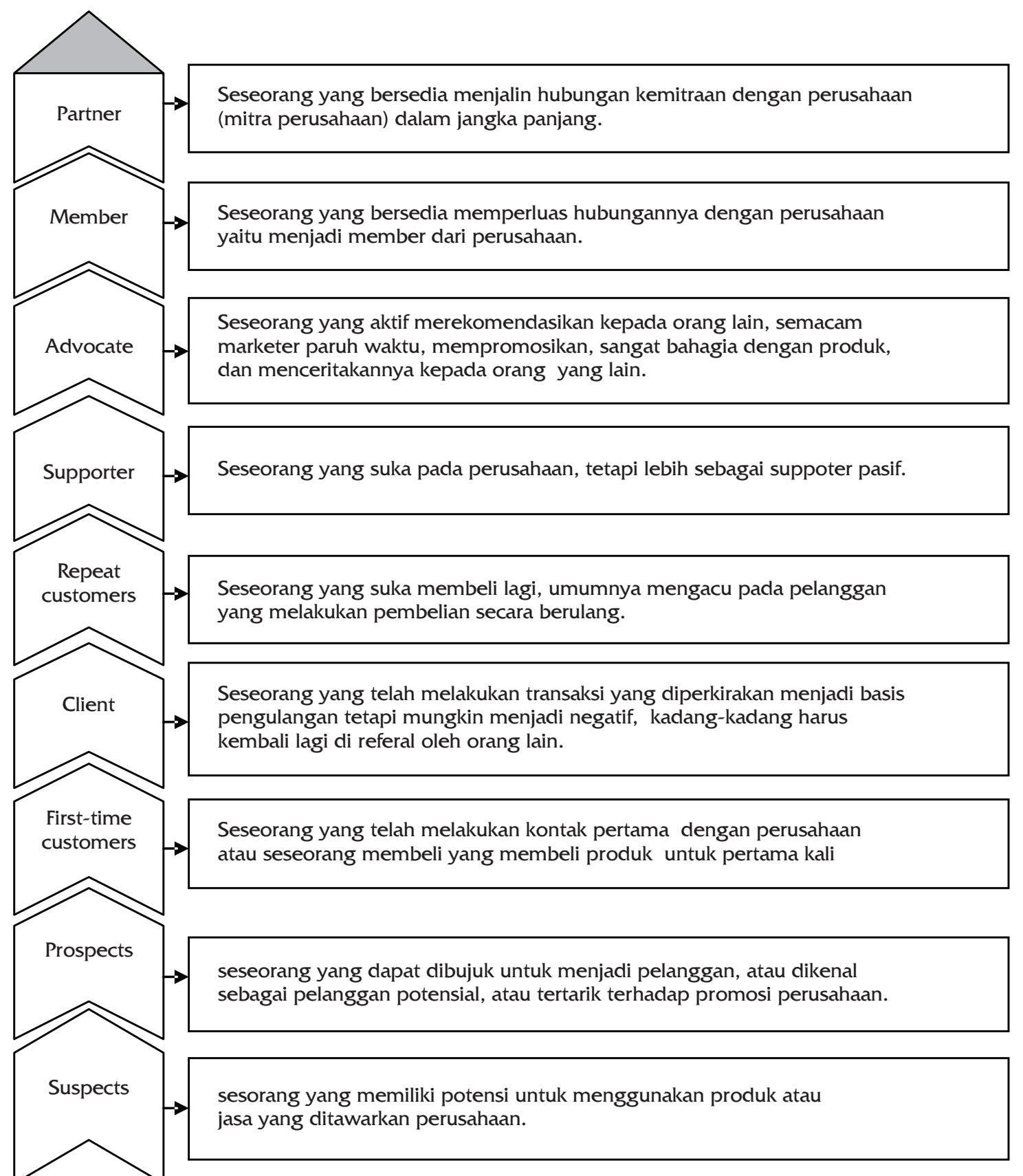

Gambar 2. Tangga Pengembangan Relationship Marketing 
pelanggan untuk meningkatkan nilai hubungan pelanggan melalui: (1) Core produk sebagai bagian khusus dari rantai nilai pelanggan. Supplier dapat meningkatkan produk inti dan layanan untuk mengurangi biaya pelanggan, (2) Layanan yang lebih luas. Meningkatkan nilai rantai pembelian terkait dengan pengalaman total. Ini berarti bahwa penjual bisa memberikan layanan yang lebih bagi pelanggan untuk mencapai pelanggan dan (3) Jumlah alternatif penyelesaian, keterlibatan karyawan dalam penjualan dapat menciptakan pembeli yang puas atau mencapai target adopsi pelanggan dan keterkaitan saluran komunikasi antara pelanggan dan perusahaan.

\section{Peran Nilai Tambah}

Peran nilai tambah (added-value) adalah bagaimana bisnis berusaha untuk mendapatkan posisi laba dan umpan balik terbaik antara pelanggan dan perusahaan

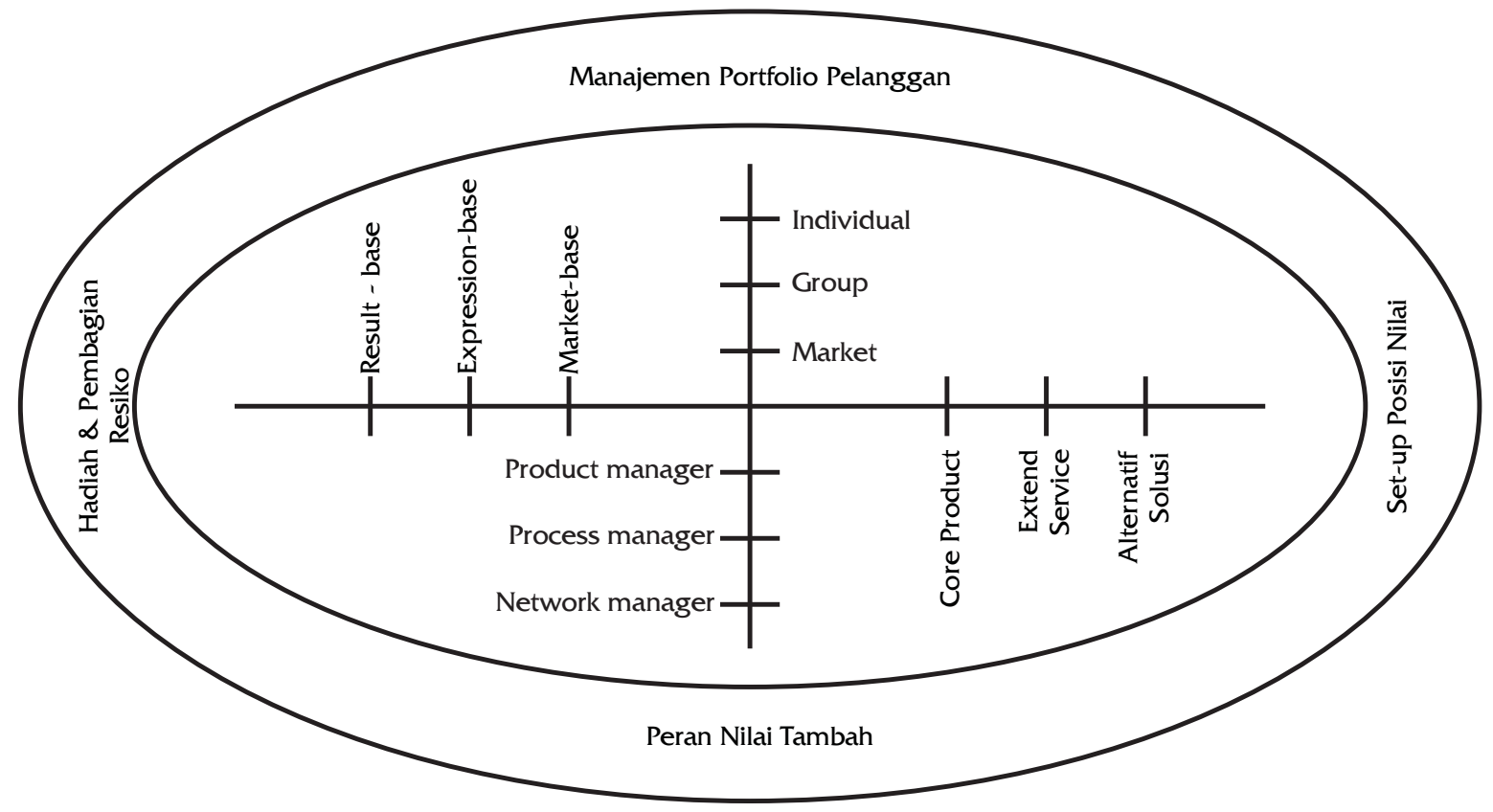

Gambar 3. Perspektif Nilai Hubungan

dalam rantai nilai terkait, melalui : (1) produk manager, menciptakan serangkaian kegiatan saling terkait dan perilaku bisnis yang menyediakan produk ke pembeli, (2) proses manajemen, menciptakan multi-model yang menghubungkan pelanggan dengan perusahaan. Proses hubungan pelanggan melibatkan posisi nilai yang mengacu pada nilai tukar yang lebih luas, dan (3) jaringan manajemen, yang melibatkan multi-perspektif antara pembeli dan perusahaan dan hbungan dengan grup terkait.

\section{Pembagian risiko}

Hubungan yang interaktif antara pelanggan dan perusahaan adalah fondasi penciptaan nilai dan sharing nilai melalui tiga model : (1) base market sharing, model dasar dan pembagian risiko imbalan, yang umumnya diputuskan oleh pasar dan memiliki karakteristik netral. (2) base expression sharing, Di masa depan, operasi harga pada beberapa produk akan terus berlanjut terutama bagi yang suka mengambil risiko dalam ketidakpastian. Mereka biasanya menentukan risiko dengan negosiasi untuk mengembangkan dan memperluas hubungan. Jaminan kualitas dan purna menjual adalah model umum pengambilan risiko. (3) base result sharing, bermitra dengan semua orang yang paling berarti dalam mengambil risiko.

\section{KERANGKA KERJA RELATIONSHIP MARKETING}

Dalam setiap keputusan marketing memiliki implikasi terhadap sumber daya yang cukup besar, tetapi belum tentu menghasilkan ROI yang besar, oleh karena itu perlu dilakukan analisis biaya-manfaat atas investasi RM. Misalnya saja, pada jenis produk yang sering dibeli (seperti pasta gigi), tingkat perbedaan convenience pelanggan dan margin keuntungan masing-masing produk, demikian juga pada perusahaan yang menggunakan media sosial marketing untuk membedakan berbagai merek yang muncul di supermarket dan toko diskon mungkin sulit untuk mendapatkan ROI dari investasi atas aplikasi RM. Sebaliknya dalam industri mesin dan keuangan dengan adopsi pilihan media sosial terkait secara langsung dengan alat yang nyaman untuk menyediakan layanan pelanggan dan kegiatan penjualan, aplikasi RM justru akan menghasilkan nilai CLV yang tinggi, dan terjadi kecenderungan peningkatan kepuasan pelanggan. ${ }^{19}$ 
Keberhasilan RM sangat dipengaruhi kemampuan perusahaan dalam mendorong first time buying ke dalam bentuk hubungan jangka panjang yang dapat bermanfaat bagi perusahaan dan konsumen. Untuk itu perusahaan harus mampu menggabungkan penggunaan sumber daya perusahaan dan pasar dalam meningkatkan hubungan yang kuat dengan pelanggan, karyawan, mitra bisnis, dan pemegang saham.

Pertama, mengoptimalkan semua asset baik asset berwujud maupun asset tak berwujud yang digunakan untuk mendeskripsikan nilai baik untuk kepentingan internal perusahaan maupun eksternal perusahaan. Oleh karena itu nilai pasar (market value) yang sesungguhnya harus sama dengan nilai buku (book value), memperbesar nilai pasar atau sebaliknya - berarti marketer/ manajemen telah melakukan pembohongan terhadap dirinya sendiri, perusahaan, mitra bisnis maupun publik. Dalam value relationship marketing bahwa aktiva atau asset didefinisikan sebagai segala sesuatu yang dapat menjadi sumber yang secara potensial mempunyai kapasitas dalam memberikan manfaat ekonomi serta memiliki kontribusi positif terhadap nilai perusahaan secara keseluruhan baik sekarang maupun pada masa yang akan datang (all potential sources of future economic benefit). Asset ini digolongkan menjadi dua, (1) asset berwujud adalah semua yang dapat dilihat dan dipegang, dihitung dan ditimbang disebut aktiva fisik (physical assets) yang bentuk wujudnya mencakup tanah, bangunan, peralatan dan persediaan. (2) asset tidak berwujud dalam bentuk financial assets, employee and supplier assets, customer assets dan organization asset yang digunakan untuk mengoptimalakan relasi yang menghubungkan kemampuan internal dan kekuatan ekternal perusahaan dalam membimbing arah kegiatan bisnis secara optimal, efisien dan efektif guna menciptakan nilai pelanggan. $^{20}$

Kedua, model pasar relationship marketing (gambar $4)^{21}$ digunakan untuk meninjau ulang peran yang

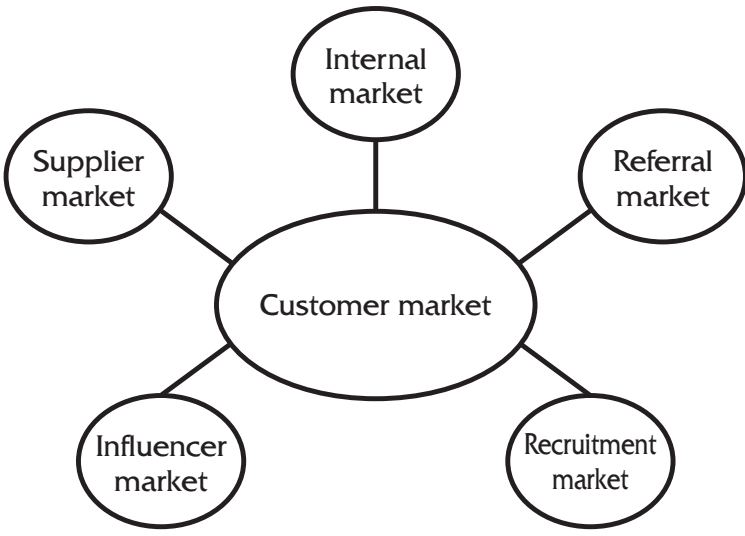

Gambar 4. Model Pasar RM

dimainkan oleh perusahaan dalam menciptakan total nilai perusahaan. Interaksi peng-gunaan model pasar dapat (a) mening-katkan skala ekonomi jangka panjang dan nilai bagi semua stakeholders (b) meningkatkan capaian kinerja bisnis. Elemen pasar RM ini terdiri dari :

\section{Customer Markets}

Customer markets (pasar pelanggan) adalah domain inti dari model RM, pasar pelanggan memiliki power dan karenanya menjadi focus semua aktivitas pemasaran. Aktivitas pemasaran perlu berkonsentrasi pada upaya menciptakan, memelihara dan mempertahankan pelanggan yang menguntungkan. Perusahaan perlu memusatkan perhatian pada proses membangun hubungan jangka pan--jang dengan pelanggan dan gene-rator pemblian ulang. Cara ini akan menciptakan mata rantai nilai lebih kuat antar proses internal dan kebutuhan pelanggan, menghasilkan tingkat kepuasan pelanggan yang lebih tinggi. ${ }^{22}$

2. Referral Markets

Dalam referral markets (rujukan pasar) terdapat dua pemain kunci yaitu pelanggan (customer) dan non pelanggan (non-customer). Dalam jenis pasar ini, marketer terbaik adalah apabila pelanggan yang puas mampu menciptakan rekomendasi positifyang kuat kepada orang lain. Partisipasi non-customer sering juga mempunyai dampak positif dalam merekomendasikan perusahaan ke calon pelanggan misalnya jaringan, penyalur, agen dan introduksi pihak ketiga lainnya. Kedua jenis referral markets ini dapat digunakan untuk menerapkan rencana pemasaran guna merangsang referensi. Meskipun dalam waktu berbulan-bulan belum melihat efek referral markets, akan tetapi sering merupakan bagian paling efektif dari rencana pemasaran secara keseluruhan dan penggunaan sumber daya terbaik dalam pemasaran.

3. Supplier and Alliance Markets

Para suppliers (penyalur/pemasok) perlu diperlakukan sebagai mitra. Para penyalur atau penjual dan anggota aliansi menyediakan sumber daya phisik seperti bahan baku, produk dan komponen untuk dipasok ke perusahaan. di pasar jenis ini perlu juga diperlakukan sebagai mitra. Peran anggota aliansi sebagai mitra adalah menyediakan kompetensi, kapabilitas dan knowledge based menjadi product based. Market supplier dan alliance ini bertujuan untuk memastikan bahwa hubungan jangka panjang itu harus bebas dari konflik di mana semua pihak memahami kebutuhan dan melebihi harapan satu sama lain. Strategi dapat mengurangi biaya dan meningkatkan kualitas.

4. Influence Markets

Influence market pada umumnya mempunyai cakupan kelompok komponen yang berbeda. sebagai contoh, pemegang saham, analis keuangan, makelar saham, media, preser bisnis, kelompok konsumen dan pemakai, perserikatan dan asosiasi profesional. Masing-Masing kelompok ini 
mempunyai suatu pengaruh penting pada perusahaan, produk dan jasa mereka. Pandangan ini didukung oleh tujuan RM yaitu creator nilai untuk kedua belah pihak melalui hubungan dan partnership dalam pasar. Oleh karana aktor utamanya adalah pelanggan, maka marketer perlu kerjasama dengan stakeholders dan mitra lain yang dapat mempengaruhi dan mendukung operasi pemasaran perusahaan. ${ }^{23}$ Influence market melibatkan berbagai sub-influencer termasuk: regulator pemerintah, badan standarisasi mutu, pelobi, pemegang saham, bankir, ventura, analis keuangan, pialang saham, asosiasi konsumen, asosiasi lingkungan, dan asosiasi tenaga kerja. Walaupun kegiatan sub-influencer ini biasanya dilakukan oleh departemen marketing, akan tetapi hubungan pemasaran dalam kaitannya dengan pasar adalah tanggung jawab setiap orang dalam perusahaan. Setiap pasar memerlukan strategi bauran pemasaran yang eksplisit, dan terpisah untuk masing-masing market.

\section{Recruitment Markets}

Orang yang diterima merupakan asset utama bagi perusahaan. Perusahaan harus (a) menemukan karyawan yang sangat potensial dan (b) melakukan segalanya untuk mempertahankan orang-orang yang paling tinggi mutunya. Setiap asset perusahaan akan menjadi pendukung ysng bernilai bagi operasi perusahaan, mendorong perusahaan sukses masa depan. Recruitment market menjadi penting untuk setiap perusahaan karena karyawan menjadi unsur kunci dalam memelihara power dan mengambil manfaat dari kompetisi dalam pertarungan merek pasar.

6. Internal Markets

Internal market masih sering diremehkan oleh banyak perusahaan. Pemasaran dapat memainkan peran sangat penting bersama dengan sumber daya manusia untuk menjamin dan memastikan bahwa proses operasi dan pertukaran pasar internal bekerja secara efisien. Setiap karyawan di setiap departemen dalam perusahaan adalah pelanggan internal dan penyalur internal. Lebih dari itu, marketer perlu meyakinkan pimpinan perusahaan bahwa semua karyawan dapat bekerja sama dengan cara yang sesuai dengan misi, tujuan dan strategi.

\section{MEMBANGUN HUBUNGAN PERTUKARAN DENGAN PELANGGAN}

Sebaik apapun sumberdaya yang dipersiapkan untuk sebuah RM, tidak akan berarti apa-apa terhadap perusahaan, terutama ketika tidak mampu membangun hubungan pertukaran dengan pelanggan secara berulang. Dengan bantuan teknologi komunikasi sejumlah elemen fungsional seperti construction, community, customization, consentration, communication, connection, convergention dan commerce perlu dipertimbangkan dalam penggunaan

\section{RM. $^{24}$}

Construction - walaupun janji (iklan) yang dibuat oleh marketer tidak terlalu unik di internet, tetapi kemampuan komunikasi interaktif dapat memudahkan marketer untuk menyampaikan pesan iklan dengan cepat, andal, dan berharga. Janji harus dapat diterjemahkan ke dalam spesifik fungsi inte-raktif dan desain fitur kolektif yang mampu memberikan konsumen sebuah pengalaman terbaik. Fitur desain satu-klik untuk pemesanan dan membantu belanja otomatis yang aman dan nyaman.

Community - didefinisikan sebagai satu set hubungan yang dibangun atas dasar ketertarikan dan kepentingan yang sama. Komunitas akan berguna tergantung pelaku-pelaku hubungan, misalnya:

Komunitas dapat menciptakan konten atau layanan yang menarik pelanggan untuk mengunjungi situs Web.

- Komunitas dapat membangun hubungan yang lebih dekat antara pelanggan dan perusahaan.

- Komunitas melalui situs pengguna media sosial yang intraktif, marketer dapat mengembangkan pelanggan menjadi marketer.

Customization - kastemisasi didefinisikan sebagai kemampuan sebuah situs untuk memodifikasi dirinya sendiri agar sesuai dengan setiap pemakai. Saat kastemisasi dirancang dan diatur oleh perusahaan disebut tailoring. Saat kastemisasi dirancang dan diatur oleh pemakai disebut perso-nalisasi. Pendekatan online ini sering disebut new model customization sebagai perubahan dari model offline (tabel 3 )

Consentration - pengetahuan model perilaku untuk mengidentifikasi profil perilaku online, pembelian produk yang disukai atau tidak disukai (minat), melacak masa lalu pembelian konsumen, situs jaringan pembelian dan perilaku pada umumnya memungkinkan marketer menargetkan iklan jauh lebih efektif. Perusahaan perlu mengumpulkan informasi penargetan perilaku, memelihara database transaksi masa lalu pelanggan. Bagi konsultan marketing database ini dapat menghasil-kan uang - dijual ke agency periklanan.

Communication - menunjuk kepada dialog antara situsweb dengan pemakai, baik perusahaan ke pemakai (contoh: email notification), pemakai ke perusahaan (contoh: customer service) maupun pemakai ke pemakai (contoh: instant messanging). Ada tiga tool komunikasi yang biasa digunakan;

- broadcast, seperti : mass mailing, FAQs, email newsletter, content update notifications, broadcast events),

- interactive, seperti : e-commerce dialogue, customer service, user input, dan

- hybrid, penyisipan (kombinasi) iklan yang tepat membuat iklan yang sangat relevan

Pastikan bahwa marketer mendengarkan pelanggan dan karenanya pelanggan tetap ingin terhubung dengan marketer/perusahaan. 
Tabel 3 Segmented Marketing vs Customization Marketing.

\begin{tabular}{|c|c|c|c|}
\hline \multicolumn{2}{|r|}{ Aspek } & Segmented Marketing & New Customization Marketing \\
\hline 1 & Hubungan Pelanggan & Partisipasi pelanggan pasif & $\begin{array}{l}\text { Pelanggan aktif sebaga co-produsen } \\
\text { - co-creation }\end{array}$ \\
\hline 2 & Kebutuhan Pelanggan & Diartikulasikan & diartikulasi dan tidak diartikulasikan \\
\hline 3 & Segmentasi & Mass market dan target segmen & Solusi individual and target pasar \\
\hline 4 & Penawaran Produk & Perluasan line produk dan modifikasi & $\begin{array}{l}\text { Kastemisasi produk, service, } \\
\text { dan marketing }\end{array}$ \\
\hline 5 & $\begin{array}{l}\text { Pengembangan } \\
\text { Produk Baru }\end{array}$ & Marketing, R \& D & $\begin{array}{l}\text { R \& D pada pengembangan } \\
\text { platform kastemisasi }\end{array}$ \\
\hline 6 & Harga & Fixed dan diskon & $\begin{array}{l}\text { Determinasi harga, dan model } \\
\text { value-based pricing }\end{array}$ \\
\hline 7 & Promosi & Periklanan and PR & $\begin{array}{l}\text { Integrated, interactive, kastemisasi } \\
\text { marketing, edukasi, dan entertainment }\end{array}$ \\
\hline 8 & Distribusi & Retailing tradisional dan direct marketing & $\begin{array}{l}\text { Direct - online } \\
\text { Menggunakan jasa logistik pihak ketiga }\end{array}$ \\
\hline 9 & Merek & Merek tradisional dan co-branding & Nama pelanggan - mirip DNA \\
\hline 10 & $\begin{array}{l}\text { Basis keunggulan } \\
\text { bersaing }\end{array}$ & Power Marketing & $\begin{array}{l}\text { Kemahiran atau keahlian marketing, } \\
\text { capturing pelanggan sebagai mitra, } \\
\text { Integrated marketing, operasi, } \\
\text { R\& D, dan informasi }\end{array}$ \\
\hline
\end{tabular}

Dalam komunikasi, percakapan (conversation) marketer dengan setiap orang berkisar tentang :

- prospek dan kemana mereka ingin berlibur (untuk penawaran wisata);

- apa yang ingin mereka bicarakan;

- upaya mempelajari profil mereka, gambar dan video di situs sosial mereka, marketer dapat belajar banyak tidak harus mengeluarkan uang, cukup dengan membayar perhatian.

Connection - didefinisikan sebagai jaringan link antara situs kita dengan situs-situs lain, link yang diklik akan membawa pemakai keluar dari situs kita dan masuk ke situs orang lain. Optional koneksi dapat melalui : link to sites, homesite background, outsourced content, percentage of homesite content dan pathway of connection. Terhubung dengan setiap orang adalah sinyal kesuksesan di media sosial dimulai. Hubungkan dengan orang-orang di twitter, facebook, linkedin, youtube, atau situs lainnya dalam lingkup sosial yang cocok. Ingat, marketer/ perusahaan harus terhubung ke orang-orang yang mencari marketer/perusahaan. Mereka akan menemukan marketer/perusahaan jika terlihat, dan dapat diakses untuk terhubung atau order produk.

Convergention - pertempuran aplikasi RM untuk mencapai pasar sasaran lewat media nirkabel menjadi lebih interaktif; integrasi suara dan merek tawaran yang menarik bagi konsumen yang dikemas dalam iklan, atau pemasaran langsung (online) baik domistik maupun global. Perusahaan perlu secara terus menerus berevolusi untuk memanfaatkan kesempatan dan melakukan manuver alam semua aktivitas marketing guna meningkatkan efektifitas pemasaran. Penggunaan teknologi broadband menjadi "tv interaktif," dalam bingkai internet yang paling sederhana dapat menampilkan iklan menarik dan mendorong pengguna mencari informasi lebih lanjut atau memesan produk.

Commerce - didefinisikan sebagai kapasitas transaksi, penjualan produk atau jasa pada sebuah situs, bersamaan dengan pengiriman dan pilihan pembayaran, che-out, konfirmasi order dan "keranjang belanja”. Fitur commerce ini paling tidak berisi registrasi, keranjang belanja, keamanan, kartu kredit, one-click shopping, orders through affiliates, pelacakan pesanan, pilihan hantaran produk. Ending dari marketing adalah dapat menawarkan barang dan jasa secara langsung ke konsumen (B2C), atau C2C termasuk word of mouth recomendation, dan B2B dengan tingkat akuisisi pelanggan yang tinggi pada tingkat biaya yang rendah.

\section{MERUBAH PELANGGAN BARU MENJADI PELANGGAN} ULANG

Begitu banyak energi yang dihabiskan marketer untuk mencoba : menarik pelanggan baru, meningkatkan kesadaran merek, membuat koneksi baru, membuat pelanggan bertahan, mengubah pelanggan baru menjadi pembeli ulang untuk yang ke 2 , ke 3 dan seterusnya, menjadikan pelanggan seumur hidup. Cara yang paling sederhana adalah jangan menjadi orang asing dengan pelanggan, dengarkan, dan ekspresikan diri dengan cara yang paling ramah. Bagi perusahaan, pelanggan yang kembali (membeli ulang) sangat penting untuk kelangsungan hidup. Setiap marketer, sangat penting untuk memahami bagaimana membangun basis pelanggan menjadi pembeli ulang dari waktu ke waktu. Ada sebelas ide strategis yang dapat dipertimbangkan: ${ }^{25}$ 


\section{Internal marketing}

RM menekankan apa yang disebut pemasaran internal. Hal ini mengacu kepada penggunaan sebuah orientasi pemasaran dalam perusahaan itu sendiri. Banyak atribut hubungan pemasaran seperti kolaborasi, kesetiaan dan kepercayaan menentukan apa yang akan dikata-kan dan di lakukan pelanggan internal. Menurut konsep ini, setiap karyawan perusahaan menjadi pemasok, layanan produk. Seorang karyawan mendapatkan pelayanan di sebuah titik rantai nilai dan kemudian menyediakan layanan untuk karyawan lainnya sepanjang rantai nilai.

Jika pemasaran internal efektif, setiap karyawan akan memberikan dan menerima layanan yang luar biasa dari dan ke karyawan lain. Ini juga akan membantu karyawan memahami pentingnya peran mereka dalam hubungan dengan orang lain. Jika diterapkan dengan baik, dapat mendorong setiap karyawan melihat proses nilai tambah dalam persepsi pelanggan. Sebuah program pemasaran internal yang efektif merupa-kan prasyarat untuk efektifitas upaya pemasaran eksternal.

\section{Searching customer}

Riset menunjukkan bahwa biaya layanan pelanggan yang sudah ada lebih murah dibanding biaya menarik pelanggan baru. Ini masuk akal, mengingat biaya iklan, pemasaran, media, dan alat-alat lainnya yang diperlukan untuk menarik pelanggan baru lebih besar. Juga, untuk mendapatkan perhatian pelanggan baru sering mendapat masalah (terutama waktu). rospek hanya akan mendengarkan pesan promosi perusahaan ketika mereka siap untuk membeli atau membuat perubahan (switch). Itu berarti marketer harus secara terus-menerus melakukan perburuan untuk menemukan orang/pelanggan yang siap untuk membuat perubahan.

3. Billboard Berjalan

Jika pelanggan datang kembali ke perusahaan, bisa dipastikan bahwa mereka menyukai apa yang dilihatnya pertama kali, dan dari sana, kemungkinan pelanggan akan menyebarkan berita atau publisitas yang gratis untuk kita. Riset terkini mempublikasikan bahwa lingkaran pengaruh secara berantai masingmasing orang berkisar antara 50 dan 300 orang. Ini bisa dibayangkan waktu yang dibutuhkan seorang marketer untuk menghasilkan 300 prospek potensial.26 Ketika marketer berhasil menciptakan pelanggan berulang dan ikatan yang kuat, dan menemukan cara untuk berkomunikasi dengan lingkaran pengaruh, perusahaan akan memiliki marketer baru atau tenaga penjual baru (gratis), tanpa menimbulkan overhead tambahan yang terus berlanjut sepanjang dikehendaki oleh marketer/ manajemen.

4. Membangun Kesetiaan Pelanggan
Walaupun perusahaan berusaha menyampaikan kualitas produk dan layanan prima di awal penjualan, repeat customer mungkin tidak akan terjadi atau mungkin sangat sedikit, tetapi keunggulan dan proposisi pelanggan ulang justru muncul ketika pelanggan memperoleh pengalaman yang konsisten dari perusahaan..

5. Mempekerjakan Orang Yang Tepat

Karena karyawan berada di garis depan, sikap dan interaksi mereka dengan pelanggan dapat mempererat hubungan yang mendorong pelanggan kembali lagi. Karyawan harus terdiri dari individu-indivdu yang positif, ramah, dan benarbenar peduli dalam melakukan pekerjaannya. Siapapun yang akan berinteraksi dengan pelanggan, mulai dari Satpam hingga Top Manajemen harus memahami pentingnya menciptakan interaksi positif dengan pelanggan.

6. Kenali Pelanggan Dengan Baik.

Sulit untuk membangun pelanggan ulang, jika tidak tahu apa nilai yang dibutuhkan pelanggan. Salah satu cara untuk melakukannya secara efektif melalui penggunaan perangkat lunak pemasaran hubungan pelanggan (Dynamics Customer Relationship Marketing-DRM). Dengan DRM marketer dapat melacak, mengumpulkan, menyimpan dan menganalisis data pelanggan, setting sejarah pembelian, peluang penjualan dan informasi lain untuk mengenali nilai yang memang dibutuhkan pelanggan dari perusahaan.

7. Hubungan Personal

Repeat customer adalah seseorang yang kita kenal, dengan menjaga hubungan yang sangat personal. Misalnya mengenal nama, minuman dan makanan favorit pelanggan. Ini berarti, sejarah dan informasi lainnya ada dalam genggaman marketer, menghubungkan diri pada tingkat pribadi pelanggan adalah salah satu keunggulan kompetitif terbaik, semua orang menyukainya ketika mereka datang ke toko kopi dan server mengingat dan menyapa nama dan termasuk minuman favoritnya.

8. Menawarkan Belanja Ulang

Salah satu cara untuk memberi orang insentif agar tetap berbelanja atau menggunakan kembali penyedia produk/toko yang sama, adalah memberikan kupon diskon agar mereka kembali ke toko yang sama :

a. Pemberian kupon, pastikan kupon belanja itu menjadi alasan untuk mencari lagi karena sesuatu yang bermerek untuk mempertahankan dan mengasosiasikan mereka dengan merek itu, Pastikan pemberian itu dapat membantu membangun merek dan membuat pengalaman itu segar dalam pikiran mereka, pastikan mereka mengguna-kannya, jika tidak (merek itu) akan terjebak dalam kotak sampah mereka. Jika menggunakan kupon diskon sebagai cara untuk 
menargetkan pelanggan tetap, pastikan diskon itu cukup besar atau unik - lebih dari yang sudah umum digunakan oleh banyak toko atau perusahaan;

b. Pemberian diskon eksklusif, Cara lain untuk mendorong repeat customer adalah untuk memberikan diskon khusus untuk pelanggan terbaik (pelanggan yang paling menguntungkan atau orang yang memiliki sejarah yang setia). Dengan menunjukkan bahwa marketer mengenali nilai pelanggan, pelanggan merasa dihargai dan mendorong mereka untuk terus melakukan pembelian ulang. Eksklusif artinya memberi pelanggan diskon yang lebih tinggi, lebih banyak perhatian, atau akses dini untuk harga jual. Buatlah sesuatu yang memungkinkan mereka melihat seberapa banyak marketer menghargai kesetiaan mereka. Banyak pemilik bisnis melakukan hal ini dengan membuat sebuah "daftar pribadi" atau dengan kartu "member program" untuk membantu mereka merasa diakui dan dihargai sebagai "one man special".

\section{Penggunaan Mailing List}

Salah satu cara unttuk mencapai target waktu adalah dengan menggunakan e-mail, daftar e-mail memberikan marketer cara yang lebih personal untuk tetap berhubungan dengan pelanggan masa lalu, berbagi cerita bisnis, promosi atau peristiwa khusus untuk membantu konsumen kembali ke toko. E-mail marketing dari sudut pandang retensi pelanggan, bukan hanya karena memungkinkan marketer untuk memasukkan informasi promosi, tapi juga karena membantu mengembangkan hubungan yang lebih intim dengan pelanggan. Email marketer yang muncul di kotak masuk pelanggan, dapat menjadi pertanda bahwa pelanggan ingin melanjutkan hubungan sepanjang ada rasa percaya pelanggan pada marketer.

\section{Menciptakan Pengalaman Menarik}

Orang yang membeli, disamping berdasarkan merek, tetapi juga berdasarkan pengalaman. Jika marketer ingin orang untuk datang kembali dan terus melakukan bisnis dengan perusa-haan, maka marketer perlu fokus bahwa marketer sedang membangun pengalaman dengan pelanggan. Caranya, bisa dipertimbangkan (a) mengirim catatan/tulisan tangan untuk berterima kasih kepada pelanggan yang telah melakukan pembelian, (b) memberi hadiah "kecil" saat mereka masih di toko. Berbagai literature menunjukkan bahwa pengalaman paling berpengaruh pada pelanggan untuk menghabiskan uang dengan perusahaan yang sama atau tidak.

\section{Live Contact Marketing (LCM)}

Mendorong bisnis yang berulang dengan tetap berhubungan dengan pelanggan melalui newsletter, blog, atau mobile lain untuk memfasilitasi komunikasi terus berlangsung. LCM adalah istilah yang digunakan untuk menggambarkan varian komunikasi pemasaran dan periklanan di mana target konsumen dipersilakan menggunakan sampel produk/merek dalam suasana santai selama jangka waktu yang lama. Sama seperti penempatan produk dalam iklan televisi, LCM dikembangkan sebagai sarana untuk mencapai sasaran segmen demografis. Praktik LCM memerlukan portofolio pemasaran berbasis tim agar poin kontak antara perusa-haan dan pelanggan lebih banyak, obligasi semakin kuat, dan hubungan lebih aman. Ide di balik teknik ini adalah bahwa pengguna akhir akan memiliki sikap positif terhadap merek sehingga mendorong rekomendasi dari mulut ke mulut dan pembeli potensial masa depan, karenanya perusahaan akan mendapat keuntungan yang signifikan pada tingkat biaya promosi yang sangat rendah.

\section{PROGRAM RELATIONSHI MARKETING}

Pengembangan program RM merupakan upaya personalisasi hubungan antara perusahaan dan pelanggan. Hubungan yang dipercaya paling sukses adalah di mana "marketer dan pelanggan menunjukkan peran perilaku persaudaraan, sahabat, dan sejenisnya untuk mendukung bentuk kemitraan atau aliansi". Tujuan program ini adalah untuk menghasilkan tingkat retensi yang tinggi dan kepuasan pelanggan yang lebih tinggi dari pesaing.

Ada dua hal penting bagi marketer : (a) menghubungi pelanggan melalui e-mail atau teknologi relational lainnya untuk mengetahui respon pelanggan terhadap pesan pemasaran, dan (b) menya-dari bahwa kepuasan atau ketidakpuasan pelanggan terbentuk dari perbandingan ekspektasi dan kinerja produk, ekspektasi pelanggan itu sendiri terus menerus meningkat karena tekanan tawaran pesaing, dan kebutuhan pelanggan berubah. Berbagai validasi empiris menunjukkan bahwa terda-pat hubungan positif yang sangat kuat antara kepuasan pelanggan dan keuntungan. Dengan demikian, para marketer harus terus-menerus mengukur tingkat kepuasan dan mengembangkan program yang membantu menciptakan kinerja produk melampaui harapan pelanggan. Sejumlah program hubungan pelanggan yang secara khusus dilakukan berkaitann dengan :

\section{Layanan Pelanggan}

Karena pelanggan memiliki lebih banyak pilihan dan pelanggan sasaran paling berharga bagi perusahaan, layanan pelanggan harus mendapat prioritas tinggi dalam perusahaan. Dalam pengertian umum, ada titik sentuh antara seorang pelanggan dengan perusahaan adalah pertemuan layanan pelanggan dan memiliki potensi untuk mendapatkan bisnis yang berulang dan membantu RM memiliki efek positif. 
Program yang dirancang untuk meningkatkan layanan pelanggan biasanya terdiri dari dua jenis. Pertama, layanan reaktif adalah ketika pelanggan memiliki masalah (produk gagal, pertanyaan tentang tagihan, pengembalian produk) dan meminta perusahaan untuk menyelesaikannya. Respon terhadap ini pada sebagian besar perusahaan membangun infrastruktur untuk menghadapi layanan reaktif melalui nomor telepon pengaduan, alamat e-mail, dan berbagai solusi lain; Kedua, layanan proaktif, marketer memutuskan untuk tidak menunggu pelanggan menghubungi perusahaan, tetapi lebih agresif membangun dialog (conversation) dengan pelanggan sebelum mengeluh atau perilaku lainnya yang memicu solusi reaktif. Account manajemen, tenaga penjualan atau siapapun (mitra internal) yang berurusan dengan pelanggan dilatih untuk menjangkau dan mengantisipasi kebutuhan pelanggan.

Memanfaatkan berbagai sistem web dapat membantu kedua jenis layanan tersebut. Perusahaan dapat membuat web atau media sosial lainnya yang memungkinkan pelanggan untuk menghubungkan diri mereka ke semua layanan perusahaan. Layanan berbasis web lainnya menyediakan pelanggan kemampuan untuk berinteraksi dengan layanan perusahaan secara real time. Untuk tujuan ini, perusahaan perlu menginvestasikan uang dalam jumlah yang cukup guna menyediakan media informasi ketersediaan produk, status order, dan topik lain yang berhubungan dengan layanan.

Aplikasi RM memungkinkan adanya konsistensi dan akurasi penerimaan berbagai informasi penting dari semua titik kontak dengan pelanggan, baik via layanan EFT (electronical funding teransaction), Call Services Center, staf pemasaran, maupun lewat staf layanan di lapangan. Akurasi dan kelengkapan informasi memungkinkan perusahaan melakukan layanan yang lebih baik dalam penjualan retail produk. Layanan penjualan produk dan jasa yang lebih baik dapat mendorong loyalitas pelanggan dan menghindari perpindahan pelanggan ke perusahaan lain.

\section{Meningkatkan Kepuasan}

Kepuasan, adalah manfaat yang dirasakan tidak sama - atau lebih tinggi dari yang diharapkan. RM bergantung pada komunikasi dan persyaratan akuisisi berasal dari pelanggan dalam pertukaran yang saling menguntungkan, kontak dengan pelanggan yang memiliki relevansi khusus dengan kepuasan pelanggan.

Harga relatif dan kualitas produk, serta layanan penunjang yang diproduksi atau dijual, umumnya menentukan jumlah penjualan relatif terhadap perusahaan pesaing. Meskipun kelompok yang ditargetkan melalui hubungan pemasaran berjumlah besar, akurasi dan relevansi komunikasi pelanggan lebih tinggi, tetapi kurang potensial untuk menghasilkan keuntungan dari pemasaran langsung dan terbatas bagi viral marketing dalam akuisisi pelanggan. RM memiliki kemampuan untuk memfasilitasi perusahaan dan pelanggan melalui :

a. Ketersediaan produk memiliki efek positif pada kepercayaan bahwa pelanggan mau terlibat dalam hubungan bisnis.

b. Transfer informasi yang efisien dapat meningkatkan komitmen pelanggan terhadap bisnis.

c. interaksi dengan pelanggan meningkatkan meningkatkan komitmen dalam pandangan pelanggan.

3. Meningkatka Loyalitas

Program loyalitas memberikan penghargaan kepada pelanggan yang melakukan pembelian berulang. Banyak department store, apotek, toko kelontong, merchandiser, pakaian khusus menemukan tiga masalah utama dengan program ini : kelompok yang mahal, kesalahan yang sulit diperbaiki, didimana pelanggan memandang perusahaan sebagai pengambil manfaat dari pelanggan, dan mereka bekerja bukan untuk meningkatkan loyalitas. ${ }^{27}$ Pada kasus perusahaan penerbangan, program loyalitas bisa sangat sukses dengan meningkatkan switching cost pelanggan, membangun hambatan biaya peralihan. ${ }^{28}$ Sejumlah perusahaan berbasis web yang menyediakan insentif bagi kunjungan berulang ke situs web mereka. Walaupun belum sangat sukses, tetapi jelas bahwa orientasi ini banyak menciptakan kebutuhan program yang dapat menghasilkan perilaku setia.

Program loyalitas yang baik adalah didefinisiakan sebagai program jangka panjang yang berorientasi pada upaya membentuk akumulasi pengalaman pelanggan (yang menyenangkan : rasional, dan emosional, bahkan mungkin spiritual) menerima program loyalitas yang khas. Dengan berfokus pada program jangka panjang, termasuk program promosi yang menawarkan manfaat langsung, seperti kartu loyalitas di toko grosir - kelontong. Program diskon kartu loyalitas dari perspektif desain memerlukan tiga spesifikasi kunci: (1) participation requirements, (2) point structure, dan (3) rewards.

Banyak retailer memperkenalkan program meningkatkan loyalitas pelanggan. Efektivitas dan populeritasnya program ini di kalangan konsumen cenderung tergantung pada desain program yang menunjukkan kekuatan manfaat program diskon dan manfaat tabungan point bagi pelanggan (anggota). Bukti ini setidaknya berhubungan dengan sebagian fakta, bahwa perbe-daan pengeluaran antara anggota dan non-anggota, sebagian didorong oleh pelanggan yang paling setia dalam program loyalitas. ${ }^{29}$ Mata rantai kesetiaan pelanggan dan mutu hubungan mencakup kepuasan hubungan, komitmen dan 
kepercayaan. design, investasi hubungan dan kualitas hubungan yang tinggi memungkinkan pelanggan untuk percaya pada perusahaan.

Untuk membangun hubungan jangka panjang dengan pelanggan, praktisi marketing perlu menyadari bahwa kesetiaan merupakan sasaran dan indikator penting dalam meningkatkan pembelian ulang dan rekomendasi dari mulut ke mulut positif. Para akademisi meyakini bahwa kesetiaan pelanggan dan rekomendasi dari mulut ke mulut positif adalah hasil RQ. Hubungan jangka panjang akan terjadi apabila pelanggan percaya pada perusahaan dan saling percaya bahwa hubungan itu bermanfaat bagi keduanya.

Hasil evaluasi pelanggan terhadap RQ menjadi keputusan penting bagi pelanggan apakah mereka melanjutkan atau meninggalkan hubungan itu. Komitmen, resolusi konflik, komunikasi yang efisien dan kepuasan sebagai dimensi RQ ditempatkan sebagai mediasi kepercayaan, kegunaan sosial dan manfaat perawatan hubungan berpengaruh signifikan terhadap kesetiaan pelanggan dan kesediaan menjadi talker perusahaan (rekomendasi positif) secara lisan (resiko reputasi) kepada orang lain (keluarga, teman atau rekan kerja) untuk menggunakan produk atau perusahaan yang sama di masa depan30 (baik untuk investasi atau pembelian).

4. Meningkatkan Retensi

Faktor kunci RM adalah retensi pelanggan melalui cara-cara dan variasi praktek untuk memastikan pembelian ulang dari pelanggan yang sudah ada dengan satu syarat yaitu kepuasan pelanggan pada perusahaan yang sedang bersaing. RM digunakan sebagai sarana penyeimbang pelanggan baru dan peluang pelanggan saat ini dalam memaksimalkan keuntungan sekaligus menangkal leaky bucket theory of business. Kajian empiris menunjukkan, banyak perusahaan mengalokasikan sumber daya yang mencapai rata-rata 5 - 10 kali lipat untuk menarik pelanggan baru - menciptakan transaksi baru (marketing ofensif), walaupun dampaknya terkadang tidak signifikan terhadap profitabilitas. Salah satu upaya retensi pelanggan adalah penggunaan model 'defensif marketing' yang lebih dikenal dengan nama RM. Peningkatan retensi berpengaruh pada peningkatan profitabilitas karena beberapa faktor:

a. Biaya akuisisi terjadi hanya pada awal hubungan, sehingga semakin lama hubungan, biaya amortisasi semakin rendah.

b. Akun biaya pemeliharaan menurun sebagai persentase dari keseluruhan biaya (atau persentase dari pendapatan).

c. Pelanggan jangka panjang cenderung kurang berminat untuk beralih, dan juga cenderung kurang sensitif terhadap harga. Hal ini dapat mengakibatkan peningkatan volume penjualan atau setidaknya satuan volume penjualan stabil.

d. Pelanggan jangka panjang dapat menciptakan promosi dari mulut ke mulut tanpa biaya.

e. Pelanggan jangka panjang lebih cenderung untuk membeli produk tambahan dan produk tambahan ini biasanya memiliki margin tinggi.

f. Pelanggan yang bertahan cenderung puas dan kecil kemungkinannya untuk beralih ke pesaing, sehingga sulit bagi pesaing untuk memasuki pasar atau meraih pangsa pasar.

g. Biaya layanan untuk pelanggan yang setia biasanya cenderung lebih murah karena mereka akrab dengan proses, membutuhkan lebih sedikit saran, dan konsisten dalam pesanan.

h. Peningkatan retensi pelanggan dan loyalitas membuat pekerjaan karyawan lebih mudah dan lebih memuaskan. Pada gilirannya, karyawan yang bahagia akan berusaha memberikan kepuasan pelanggan yang lebih baik.

Dalam usaha membangun retensi pelanggan, marketer perlu memasukkan berbagai pertim-bangan ${ }^{31}$ berikut :

a. Penilaian pelanggan mendiskripsikan nilai pelanggan dan mengelompokkan mereka sesuai dengan nilai keuntungan sehingga perusahaan dapat memutuskan pelanggan mana yang perlu tambahan investasi untuk hubungan yang lebih mendalam dan perlu dilayani secara berbeda atau bahkan dihentikan.

b. Pengukuran retensi pelanggan, menghitung "tingkat retensi pelanggan" untuk mengetahui persentase pelanggan yang bertahan dari awal tahun sampai akhir tahun. Peningkatan retensi $10 \%$ dikaitkan dengan dua kali lipat dari rata-rata hubungan pelanggan (5 sampai 10 tahun). Rasio ini dapat digunakan untuk membuat perbandingan antar produk, antar segmen, dan dari waktu ke waktu.

c. Alasan beralih, cari dan temukan akar penyebab, bukan hanya gejala, temukan rincian ketika berbicara dengan mantan pelanggan. Penggunaan analisis keluhan pelanggan dan benchmarking kompetitif dapat membantu menyelesaikan masalah ini.

d. Pendekatan kuratif, mengembangkan dan menerapkan rencana kuratif dengan tindakan untuk meningkatkan praktek layanan karyawan, gunakan pembanding untuk menentukan praktik kuratif terbaik, dukungan manajemen puncak, penyesuaian hadiah dan sistem pengakuan, penggunaan "tim pemulihan" untuk menghilangkan penyebab pembelotan pelanggan.

e. Program retensi, secara khusus program ini dirancang paling tidak untuk : 
- membangun hambatan beralih, dilakukan dengan bundling produk (menggabungkan beberapa produk atau layanan ke dalam satu "paket" dan menawarkannya dengan harga tunggal),

- program loyalitas, pemberian insentif untuk pembeli sering, dan mening-katkan switching costs, dan mengintegrasikan sistem komputer antar unit perusahaan.

- cross selling, menjual produk yang terkait dengan pelanggan yang sudah ada (saat ini),

- cross promotion, memberikan diskon atau insentif promosi untuk pembeli produk-produk terkait

5. Kastemisasi

Gagasan kastemisasi massal menyiratkan penciptaan produk dan layanan bagi perorangan, tidak hanya berkomunikasi dengan mereka, mengembangkan konsep dengan situs build-toorder, mengembangkan proses dan sistem untuk menciptakan produk disesuaikan dengan selera pelanggan, menciptakan proses "choice board" dimana pelanggan mengambil daftar produk dan menentukan atribut yang mereka inginkan. Ide dasarnya adalah bahwa konsumen berubah menjadi pembuat produk bukan hanya takers produk. Kastemisasi tersebut murah dan mudah dilakukan dengan informasi barang-barang (umumnya disebut "versioning"), dan tentu saja, lebih mudah dilakukan untuk informasi layanan dan produk tidak berwujud (produk jasa). Produsen dapat mengambil keuntungan dari informasi yang meningkat dari pelanggan untuk menyesuaikan produk-produk yang setidaknya memberikan tampilan yang disesuaikan dengan masing-masing pelanggan dan karenanya mereka merasa sangat puas.

Gagasan kepuasan pelanggan diperluas dengan mengubah customer relationship menjadi customer experience. Ide di balik ini adalah ketika jumlah poin kontak pelanggan meningkat dari waktu ke waktu, lebih baik dari sebelumnya untuk mengukur reaksi kontak pelanggan dan mengembangkan respon langsung terhadap pengalaman negatif. Respon ini dapat mencakup permintaan maaf yang tepat waktu dan penawaran khusus untuk mengimbangi layanan tidak memuaskan. Idenya adalah untuk memperluas gagasan tentang hubungan dari satu transaksi berbasis pengalaman dan berkesinambungan. ${ }^{32}$

6. Membangun Komunitas

Salah satu kegunaan dari webbisnis adalah untuk membangun jaringan pelanggan untuk informasi produk yang berhubungan dengan pertukaran dan menciptakan hubungan antara pelanggan dan perusahaan atau merek. Jaringan ini disebut hubungan komunitas. Tujuannya adalah untuk mengambil prospektif hubungan dengan produk dan mengubahnya menjadi sesuatu yang lebih pribadi. Dengan cara ini, marketer dapat membangun sebuah lingkungan yang membuat pelanggan lebih sulit untuk meninggalkan perusahaan.

\section{Program Reduksi Biaya Pelanggan}

dengan bantuan manjemen keuangan, ketersediaan data, besar kecilnya beban biaya, ketelitian dan ketepatan analisis inilah yang membedakan antara perusahaan yang satu dengan perusahaan lainnya. Secara internal pembebanan biaya akan memungkinkan perusahaan mengukur kemampuan laba perpelanggan, mengidentifikasi pelanggan mana yang terlalu mahal dan mana yang murah untuk dilayani, menentukan kelompok pelanggan mana yang dipertahan-kan dan mana yang dilepas, dan mendesain strategi untuk setiap pelanggan. Pelanggan dapat diklasifikasi menjadi empat kelompok, yaitu :

- Laba tinggi dan beban biaya layanan rendah,

- Laba tinggi dan beban biaya layanan tinggi,

- Laba rendah dan beban biaya layanan rendah,

- Laba rendah dan beban biaya layanan tinggi ${ }^{33}$

Berdasarkan kondisi tersebut ada tiga kemungkinan strategi hubungan yang berbeda dapat dijalankan marketer/perusahaan :

a. Strategi untuk mereduksi high cost, adalah meneliti dan menentukan penyebab terjadinya biaya tinggi itu, mungkin karena:

- pelanggannya baru, umumnya biaya dapat dikurangi pada masa mendatang seiring dengan perjalanan waktu.

- pelanggan memesan produk, kuantitasnya kecil dan skedulnya tidak dapat diprediksi

b. Strategi untuk mereduksi high cost dan meningkatkan profit: (a) jika pelanggan tidak mau kerjasama dengan perusahaan dalam mereduksi biaya pelayanan, maka perusahaan dapat memberi biaya tambahan untuk pelayanan khusus secara individual. (b) Jika margin penjualan terhadap layanan pelanggan yang mahal cukup besar, maka perusahaan dapat melanjutkan pemberian tingkat pelayanan yang sama.

c. Strategi untuk low cost - high profit, perusahaan dapat menawarkan berbagai kemudahan dan keistimawan khusus untuk mempertahankan mereka.

8. Program Perluasan Pelanggan

Dalam RM, tidak semua pelanggan layak ditarik dan dipertahankan, penggunaan pendekatan segmentasi pelanggan dapat mengidentifikasi pelanggan berdasarkan profitabilitas saat ini dan masa depan. ${ }^{34}$ Pendekatan segmentasi menyediakan informasi nilai keuangan setiap segmen, oleh karena itu perusahaan/marketer, perlu: (1) menentukan besarnya sumber daya yang 


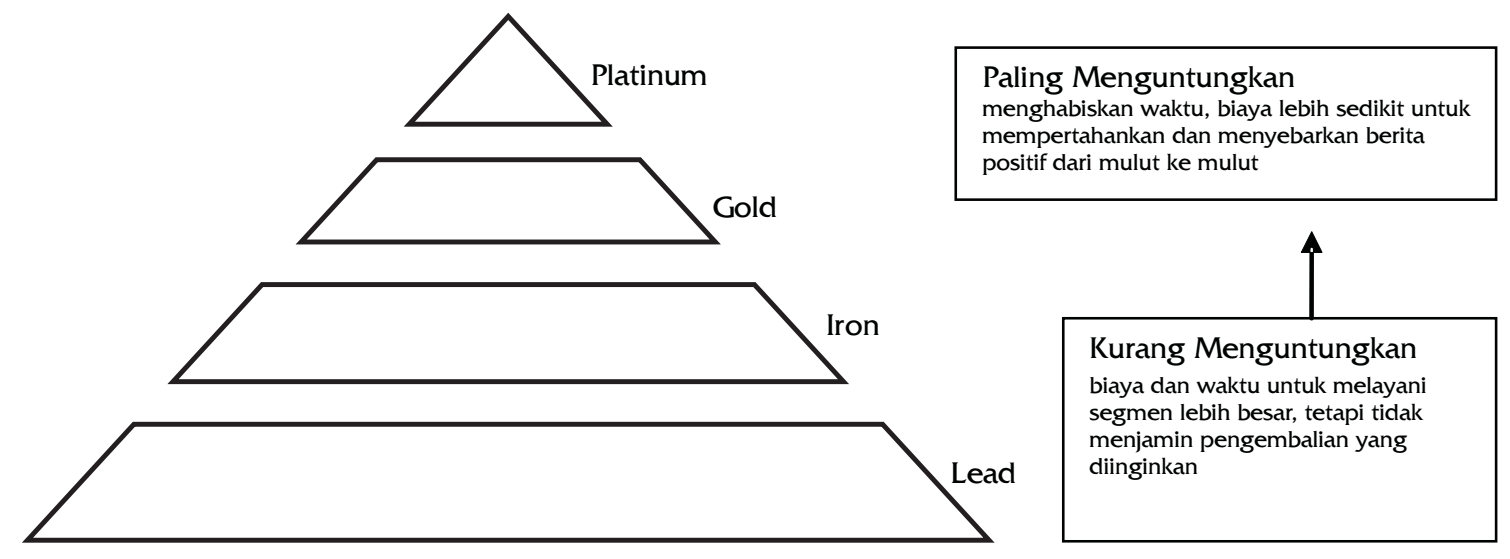

Gambar 5. Piramida Perluasan Pelanggan

dialokasikan untuk pemasaran dan penjualan, (2) membuat estimasi probabilitas dan ROI yang mungkin bisa dicapai termasuk kegagalannya (3) menentukan ragam tawaran sesuai potensi keuntungan yang mungkin diperoleh dari setiap segmen, dan (4) memfokuskan kiat layanan pada kelompok segment yang telah teridentifikasi.

Dikalangan akademisi, pada umumnya konsep $80 / 20$ teah dekenal secara luas, di mana $20 \%$ pelanggan memproduksi $80 \%$ keuntungan perusahaan dan sebaliknya membuat perusahaan menyadari situasi di mana pelanggan berbeda dalam profitabilitas. Piramida pelanggan sebagai sarana penggunaan $80 / 20$ dalam empat tingkatan (gambar 5) berdasarkan nilai profitabilitas terhadap perusahaan, sebagai berikut :

- The Platinum - adalah pelanggan yang paling menguntungkan. Pelanggan cenderung melakukan pembelian volume tinggi, tidak sensitif terhadap harga dan berkomitmen pada perusahaan.

- The Gold - kelompok ini memiliki tingkat profitabilitas relatif rendah, yang disebabkan oleh tingkat diskon dari banyak pemasok atau sikap minimisasi risiko pada sebagian pelanggan.

- The Iron - ini terdiri dari pelanggan penting yang memanfaatkan kapasitas perusahaan melalui volume tinggi. Namun profitabilitas dan loyalitas mereka tidak menjamin pengembangan hubungan yang istimewa.

- The Lead - permintaan pada tingkat ini lebih sedikit karena didominasi oleh jumlah konsumen yang besar tetapi memiliki tingkat pendapatan yang kecil.

Para akademisi marketing berpendapat (1) bahwa sebuah perusahaan membutuhkan dua tingkatan konvensional atau lebih dari yang ditawarkan oleh piramida 80/20 untuk membedakan hubungan yang harus dikembangkan pada masing-masing segmen, (2) tingkat pelayanan yang berbeda harus disediakan untuk kelompok konsumen yang berbeda tergantung pada tingkat profitabilitas mereka terhadap penawaran perusahaan, (3) mengembangkan hubungan dengan pelanggan platinum dan gold sebagai basis pelanggan- dan memastikan bahwa kelompok-kelompok konsumen yang memiliki keuntungan eksklusif diperlakukan dengan baik.

Strateginya, adalah memindahkan pelanggan naik ke tingkat platinum atau menghentikan karena tidak menguntungkan bagi perusahaan, caranya: Pertama, mengenakan biaya minimum ketika terjadi sejumlah transaksi tertentu, sehingga mendorong pembeli untuk menggunakan pemasok tunggal. Kedua, perusahaan harus menyadari ketika terlibat dalam RM bahwa tidak semua pelanggan harus diperlakukan sama. Pelanggan yang berbeda akan mewakili berbagai tingkat profitabilitas bagi perusahaan, perusahaan harus mengalokasikan sumber daya yang sesuai untuk membangun hubungan dengan pelanggan yang menawarkan potensi keuntungan terbesar bagi perusahaan. Pelanggan yang tidak menguntungkan bagi perusahaan harus dipindahkan dari piramida atau diabaikan tergantung pada potensi mereka.

\section{IMPLEMENTASI RELATIONSHIP MARKETING}

Tahapan Implementasi Relationship Marketing

\begin{tabular}{|c|c|c|}
\hline Tahap & Jenis & Kegiatan \\
\hline I & $\begin{array}{l}\text { Analisis dan } \\
\text { review } \\
\text { pelanggan }\end{array}$ & $\begin{array}{l}\text { - mempelajari kondisi hub- } \\
\text { ungan pelanggan dengan } \\
\text { perusahaan saat ini } \\
\text { - membentuk kelompok niche } \\
\text { market untuk mengiden- } \\
\text { tifikasi apakah ada kesen- } \\
\text { jangan value di pasar } \\
\text { - menentukan poin pembe- } \\
\text { lotan pada saat para pelang- } \\
\text { gan membuat keputusan } \\
\text { cacat tentang perusahaan } \\
\text { - kategorikan kekuatan hubu- } \\
\text { ngan mulai dari yang terbaik } \\
\text { sampai terburuk }\end{array}$ \\
\hline
\end{tabular}




\begin{tabular}{|c|c|c|}
\hline Tahap & Jenis & Kegiatan \\
\hline & & $\begin{array}{l}\text { - membangun hambatan } \\
\text { beralih ke perusahaan lain } \\
\text { dan mengurangi pembelotan } \\
\text { pelanggan lebih lanjut }\end{array}$ \\
\hline II & $\begin{array}{l}\text { Re-struktu } \\
\text { risasi }\end{array}$ & $\begin{array}{l}\text { - mengakomodir kemampuan } \\
\text { untuk membangun dan } \\
\text { memelihara hubungan } \\
\text { pelanggan. } \\
\text { - bekerja sama dengan semua } \\
\text { jenis usaha pemasaran } \\
\text { langsung dalam hubungan } \\
\text { yang terus berkembang. }\end{array}$ \\
\hline III & Mendidik & $\begin{array}{l}\text { secara terus mendidik diri } \\
\text { sendiri dalam melakukan kontak } \\
\text { langsung maupun tidak } \\
\text { langsung dengan setiap - semua } \\
\text { pelanggan. }\end{array}$ \\
\hline IV & Pemantapan & $\begin{array}{l}\text { - me nyebarkan in isiasi } \\
\text { pemasaran hubungan berkaitan } \\
\text { dengan setiap pelanggan dalam } \\
\text { portofolio perusahaan. }\end{array}$ \\
\hline
\end{tabular}

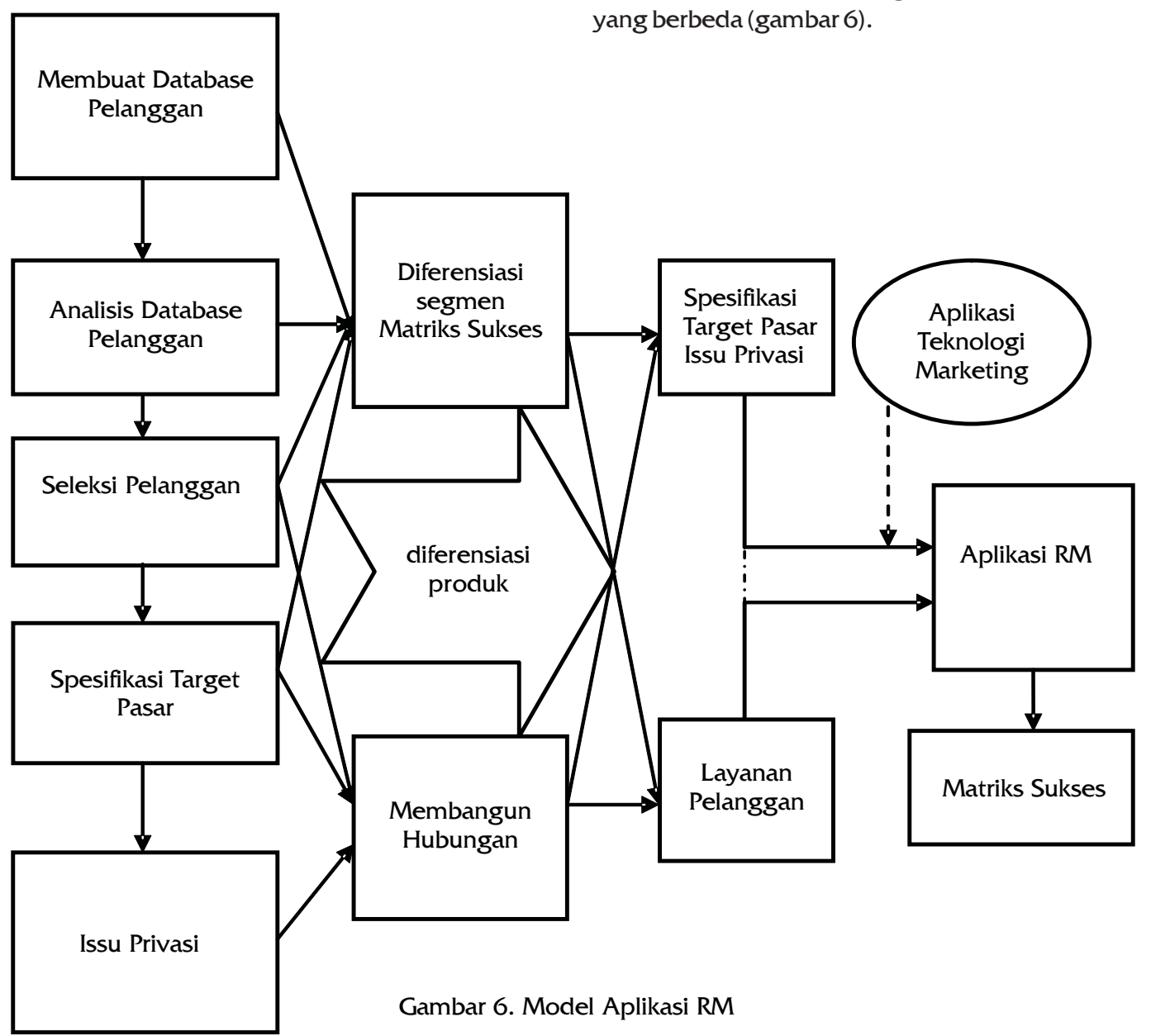

\begin{tabular}{|c|c|c|}
\hline Tahap & Jenis & Kegiatan \\
\hline & & $\begin{array}{l}\text { - mengembangkan hubungan } \\
\text { umpan balik menjadi } \\
\text { komunikasidua arah. } \\
\text { - menempatkan diri sebagai } \\
\text { wajah perusahaan kepada } \\
\text { pelanggan, penting dan } \\
\text { berharga dalam persepsi } \\
\text { setiap pelanggan }\end{array}$ \\
\hline
\end{tabular}

Pengetahuan dan implementasi RM terkait dengan kemampuan mensinergikan hubungan antar divisi, persepsi dan komitmen manajemen puncak sangat diperlukan agar RM berhasil diterapkan. Kecenderungan yang relatif sama dalam eksekusi RM adalah : mengembangkan layanan inti untuk membangun dan menyesuaikan hubungan dengan pelanggan individu, meningkatkan layanan inti untuk menghasilkan manfaat tambahan untuk mendorong loyalitas dan retensi pelanggan dalam jangka panjang.

Idealnya rancangan aplikasi RM adalah dimulai dari membuat database pelanggan, analisis database pelanggan, seleksi pelanggan, spesifikasi target pelanggan, isu privasi, membangun hubungan, analisis nilai pelanggan, layanan pelanggan, teknologi pemasaran dan matrik keberhasilan sesuai dengan diferensiasi karakteristik segmentasi, produk dan skala yang berbeda (gambar 6). 
Tuntutan Implementasi Relationship Marketing

Sejumlah tuntutan agar implementasi relationship marketing dapat mencapai hasil yang diharapkan, marketer perlu :

1. Memberdayakan perusahaan dengan data dan kontrol fleksibel

Media sosial untuk menggabungkan connected insight, mudah dan kuat, pengalaman pengguna akhir dengan kontrol dan fleksibilitas yang dibutuhkan oleh praktisi bisnis, menyediakan akses ke informasi penting di semua tingkat perusahaan. Media sosial menawarkan keuntungan unik dalam menghubungkan perusahaan dengan perusahaan internal, eksternal dan pelanggan. Dengan cara ini, koneksi RM via media sosial dapat menjadi bagian integrasi infrastruktur yang lebih besar yang mencakup manajemen kinerja; perencanaan supply chain, visibilitas, customer relationship, dan program loyalitas pelanggan. Teknologi media sosial mampu memanfaatkan peluang, mengumpulkan dan menyampaikan informasi penjualan, melakukan analisis penjualan, meningkatkan wawasan pelanggan, dan tim penjualan.

Media sosial mengintegrasikan kemampuan intelijen pemasaran dengan aplikasi bisnis dapat memberikan berbagai keuntungan, misalnya account manajer dapat menambah scorecard penjualan berdasarkan data pengecer, manajer promosi dapat mengembangkan visibilitas realtime, laba, dan mempersenjatai rantai pasokan dengan perkiraan permintaan real-time.

\section{Meningkatkan Efektifitas Marketing}

Sukses RM tergantung pada pemahaman terhadap shopper dan perilaku konsumen. Seberapa baik data penjualan - konsumsi, poin pembelanjaan, harga, ketersediaan produk, dan dampak merek adalah ukuran penting dari efektifitas marketing.

a. Optimasi promosi, menghilangkan dugaan kinerja bisnis dengan menyediakan kerangka menaikkan volume penjualan, promosi, dan informasi kinerja saat memutakhirkan proyeksi setiap hari.

b. Merchandise dan perencanaan, kolaborasi memungkinkan informasi penawaran di sejumlah besar permintaan yang dinamis, atribut produk, historis kinerja, tren, keuangan dan tujuan strategis perusahaan, akan membantu marketer dalam merencanakan dan melaksanakan tingkat pasokan produk dengan cara terbaik dan mengelola kategori tawaran produk.

c. Eksekusi ritel, aplikasi mobile yang kaya fitur mampu mengintegrasikan dan mengotomatisasi operasi sehari-hari, mengoptimalkan efektivitas, dan mempercepat informasi ke semua lini penjualan dan konsumen.

d. Repositori sinyal permintaan, memungkinkan konsumen untuk memanfaatkan kekuatan realtime, scan data point-of-sale dan efektivitas penjualan, pemasaran, rantai pasokan, operasional, dan pengembangan produk baru.

e. Loyalitas pelanggan dan analisis shopper, menggunakan seperangkat data untuk mengaktifkan pemahaman lebih mendalam perpelanggan, shopper, dan segmentasi. Dengan memanfaatkan analisis prediktif, perusahaan dapat menjamin ketersediaan produk untuk melengkapi pengalaman shopper.

\section{Optimalkan Penawaran dan Siklus Permintaan}

Informasi operasional sering tersebar di berbagai sumber, karenanya sering menjadi sulit untuk mengakses informasi yang dibutuhkan untuk memanfaatkan peluang, termasuk tingkat keberhasilan dari promosi, persediaan, dan ketersediaan produk. Perencanaan antai suplai, visibilitas, dan optimasi dihubungkan di seluruh rantai pasokan, termasuk penempatan optimal dari persediaan dalam rantai pasokan dan biaya operasi dikurangi melalui peningkatan manufaktur, transportasi, dan distribusi.

\section{Tingkatkan Efisiensi Operasional}

Otomasi penjualan dan proses layanan dapat mengurangi risiko cacatnya kualitas, mengurangi hambatan birokrasi, biaya dan kerumitan proses administrasi akan berkurang. Perusahaan dapat menyederhanakan aliran informasi dan transaksi untuk meningkatkan kecepatan waktu respon terhadap pelanggan, siklus pem-buatan, penjualan dan penyampaian produk kepada pelanggan. Kecepatan semacam itu akan meningkatkan kinerja dan akan lebih efisien.

\section{Tingkatan time to market}

Rancangan RM yang efektif dan ketersedian informasi pelanggan yang lengkap memungkinkan perusahaan membawa produk ke pasar dengan lebih cepat. Dengan keandalan ETF, dan Call Center Service akan menghilangkan hambatan waktu, komunikasi, dan geografis dalam mempercepat entry produk ke pasar. ${ }^{35}$

Model Aplikasi Relationship Marketing

Gambar 7 menunjukan lima langkah dasar sebelum relationship marketing dilaksanakan : membuat database pelanggan, analisis database, seleksi pelanggan, spesifikasi target pasar, dan issu privasi

\section{Membuat Database Pelanggan}

Langkah pertama yang diperlukan untuk sebuah RM yang lengkap adalah membangunn database atau file pelangga. Ini adalah dasar untuk mengoptimalkan power setiap aktivitas hubungan pelanggan. Untuk bisnis berbasis web, ini menjadi tugas yang relatif mudah sebagai media transaksi 
pelanggan dan akumulasi informasi kontak sebagai bagian dari interaksi dengan pelanggan. Idealnya, database itu diupdate dari waktu ke waktu berisi informasi tentang:

a. Transaksi. Ini harus mencakup sejarah pembelian lengkap dengan rincian terlampir (harga yang dibayarkan, tanggal pengiriman)

b. Kontak pelanggan. Saat ini, ada peningkatan jumlah titik kontak pelanggan dari beberapa saluran dan konteks. Hal ini seharusnya tidak hanya mencakup panggilan penjualan dan permintaan layanan, tetapi setiap kontak perusahaan - pelanggan dimulai.

c. Deskripsi informasi analisis segmentasi, targeting dan data pasar lainnya yang diperlukan.

d. Tingkat respon atas stimulus pemasaran. File pelanggan harus dipastikan berisi apakah pelang-gan menanggapi inisiatif pemasaran langsung, kontak penjualan, atau kontak lainnya atau tidak.

Perusahaan yang memiliki sistem layanan bisnis yang baik akan melibatkan interaksi pelanggan, dilengkapi dengan bantuan teknologi marketing tanpa kabel memudahkan perusahaan untuk mengumpulkan informasi pelanggan lebih baik. Tantangan terbesar menciptakan peluang interaksi pelanggan terletak pada kelengkapan data. Oleh karena itu membuat konten yang dapat mendorong kunjungan pelanggan ke situs website. Misalnya toko buku dapat menawarkan diskon $10 \%$ pada pembelian jika pelanggan memberikan informasi kepada perusahaan dan menjadi pembaca yang dipilih.

\section{Analisis Database Pelanggan}

Secara tradisional, database pelanggan dianalisis dengan maksud untuk menentukan segmen pelanggan. Berbagai metode statistik multivariat seperti klaster dan analisis diskriminan digunakan untuk kelompok pelanggan dengan pola perilaku yang sama dan data deskriptif yang kemudian digunakan untuk mengembangkan penawaran produk yang berbeda atau kampanye pemasaran langsung dengan teknik timeseries analisis untuk berbagai jenis rentang tahun untuk menentukan target prospek yang paling menguntungkan dan menyesuaikan katalog pada kelompok yang berbeda.

Praktik RM harus didorong oleh visi tentang pelanggan untuk menjadi platform keunggulan kompetitif yang nyata. Bagi sebagian besar perusahaan yang sudah memiliki database, perusahaan dapat menangkap pendapatan pelanggan dan informasi perilaku serta menggunakan alat analisis tambahan untuk menganalisis laba bersih yang sebenarnya dari pelanggan. ${ }^{36}$ Analisis ini paling tidak mencakup :

a. Kecenderungan pasar

Dalam industri komunikasi misalnya, tanggapan industri telecoms terhadap efek tekanan kompetitif dipengaruhi oleh tingkat pengembangan produk dan jasa yang memberikan nilai tambah bagi perusahaan, kemajuan digital marketing, media social, GPRS dan 3G menye-diakan platform pengiriman layanan yang sesuai dengan persyaratan dari generasi mobile. Potensi layanan dikirimkan melalui jaringan, dibatasi oleh kekuatan wallet share pelanggan.

Tren jangka panjang dalam industri terletak pada kontinuitas, dan memunculkan basis pelanggan mobile adalah perubahan dalam strategi bisnis sebagai bentuk konsentrasi akuisisi pelanggan baru pada pengembangan nilai basis pelanggan. Secara keseluruhan perlu disadari bahwa nilai seumur hidup pelanggan benar-benar berarti dari sebuah hubungan di mana fundamental transaksi penjualan, transaksi layanan atau perdagangan sangat mungkin berubah, oleh karena itu perencanaan dramatis harus dapat mengantisipasi tren pasar.

b. Customer Churn Rate

Churn rate (jumlah pelanggan yang hilang) memiliki dampak signifikan pada CLV. Ukuran tunggal churn rate termasuk dalam perhitungan tahunan umumnya dianggap sebagai indikator kinerja dengan tingkat penurunan 30\% dipandang sangat buruk. Di sisi lain tingkat penurunan 5\% akan dianggap sebagai sangat baik dan menguntungkan basis pelanggan setia. Kesimpulan ini mungkin juga benar, karena churn rate tunggal bukan kompleksitas ide yang mendasarinya, karena customer churn yang tinggi (merugikan) dapat menyebabkan peningkatan tingginya nilai deviasi CLV pelanggan - mengikis keuntungan - pendapatan perusahaan.

c. Lifestyle dan Lifestage

CLV dipengaruhi oleh lifestyle dan lifestage, dan menjadi lebih sulit mengukur CLV pelanggan ketika mereka bergerak melalui berbagai gaya dan tahap kehidupan mereka. Pendekatan yang berguna yang dilakukan adalah untuk penelitian disposable income sepanjang masa itu.

d. Kecenderungan Pelanggan

Menganalisis kecenderungan pelanggan membeli produk dan jasa tertentu, misalnya di industri keuangan, dan telecoms. Kemampuan untuk memprediksi pendapatan dan keuntungan dari basis 


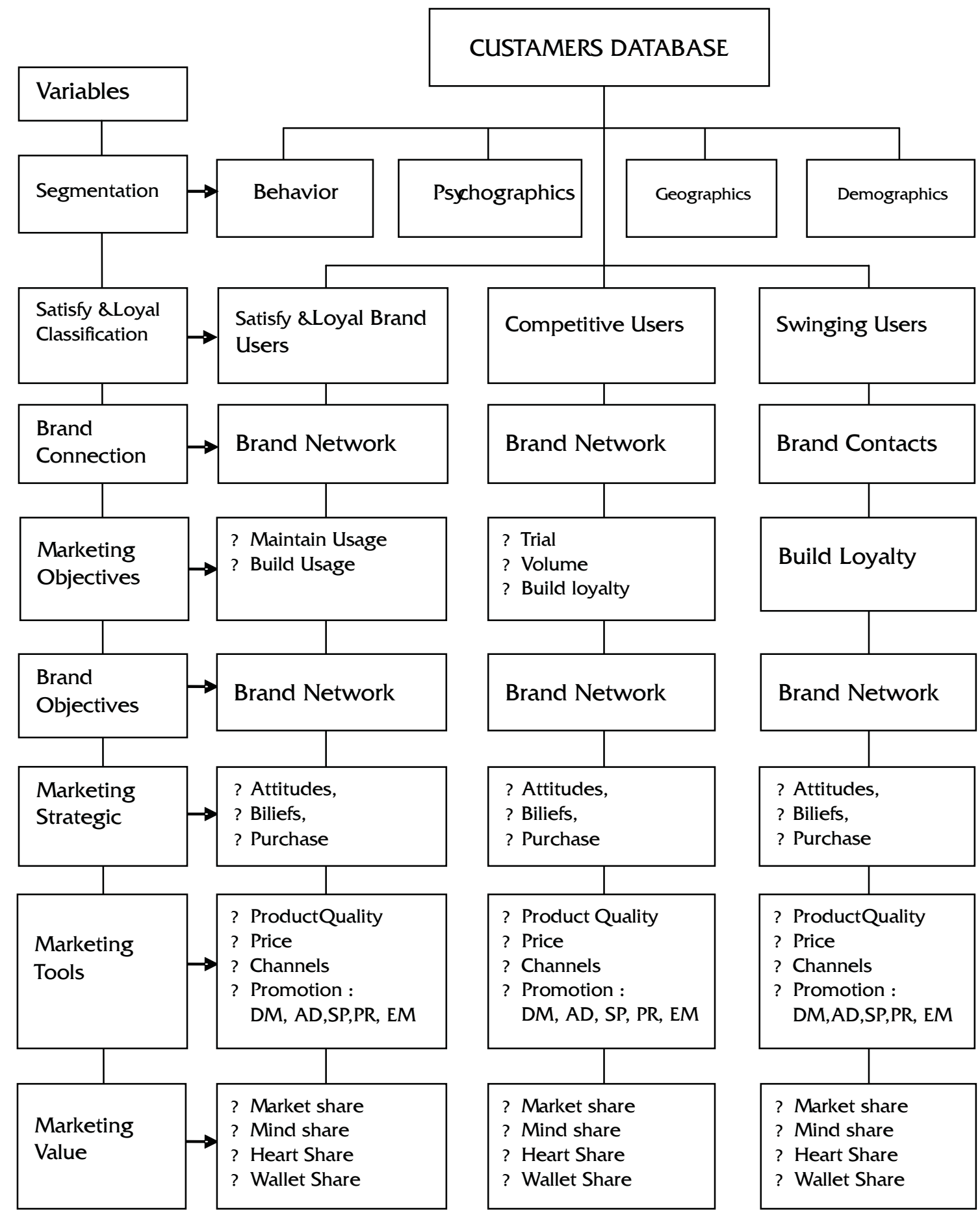

$\mathrm{DM}=$ Direct Marketing, AdAdvertising, $\mathrm{SP}=$ Sales Promotion, $\quad \mathrm{PR}=$ Public Relations, $\quad \mathrm{EM}=$ Event Marketing

\section{Gambar 7. Penggunaan Database Marketing}

pelanggan secara jelas berkaitan dengan kemampuan membuat kelompok segmentasi. Analisis perilaku menjadi semakin penting bagi marketer untuk menyediakan portofolio produk untuk target penawaran yang lebih kompetitif. ${ }^{37}$

\section{Seleksi Pelanggan}

Ketika konstruksi dan analisis informasi pelanggan yang telah tersedia dalam database, langkah berikutnya adalah mempertimbangkan pelanggan yang akan dijadikan target pemasaran. Jika jenis analisis segmentasi yang dilakukan pada pembelian atau perilaku terkait, pelanggan di segmen yang paling diinginkan (misalnya, tingkat pembelian tertinggi, loyalitas merek terbesar) biasanya akan dipilih pertama untuk program retensi. Segmen lain juga bisa dipilih tergantung pada faktor tambahan. Misalnya, promosi atau untuk pembelian, 
merangsang keputusan taktis, jika pelanggan di segmen pembelian terberat telah membeli pada tingkat yang menyiratkan pembelian lebih lanjut tidak mungkin, tingkat kedua dengan potensi yang lebih menarik. deskripsi variabel segmen (misalnya, usia, jenis industri) menyediakan informasi untuk mengerahkan perangkat pemasaran. Selain itu, variabel ini bisa disesuaikan dengan database yang tersedia secara komer-sial untuk mencari pelanggan tambahan yang cocok dengan profil yang dipilih dari database.

Jika profitabilitas pelanggan berbasis individu tersedia melalui analisis $\mathrm{CLV},{ }^{38}$ manajer pemasaran dapat menggunakan sejumlah kriteria memilih para pelanggan yang diproyeksikan akan menguntungkan. Untuk tujuan ini gunakan analisis profitabilitas pelanggan secara terpisah secara nyata memberikan keuntungan jangka panjang dari sebagian besar pelanggan yang belum maksimal memberikan keuntungan jangka panjang. Bisa jadi perusahaan mungkin akan melayani pelanggan yang relatif mahal dan tampak bertentangan dengan konsep pemasaran yang berorientasi pelanggan, namun begitu kenyataannya, tidak ada yang mengatakan bahwa pemasaran dan keuntungan yang kontradiksi dalam aturan 20/80 yang berlaku dalam perkiraan, karena pada sebagian besar laba perusahaan justru berasal dari persentase kecil pelanggan yang setia.

Intinya adalah bahwa tanpa pemahaman profitabilitas pelanggan, keputusan tidak bisa dibuat. Jika keputusan seleksi pelanggan hanya dilakukan atas dasar nilai CLV yang tinggi, dan mengabaikan atau mengusisr satu atau sejumlah besar pembeli yang secara akuntansi belum menguntungkan di grup pelanggan, belum tentu menjadi keputusan terbaik, sebab keberhasilan "mengusir" atau mengabaikan, mereka bisa saja merasa disepelekan, merasa tidak bahagia, dan karenanya mereka berubah menjadi distributor tercepat dalam menyebarkan berita negatif dari mulut ke mulut melalui media social di internet. Oleh karena itu membuat pilihan pelanggan harus dilakukan dengan hati-hati.

4. Spesifikasi Target Pelanggan

Pendekatan pemasaran massal seperti televisi, radio, atau iklan cetak yang berguna untuk menghasilkan kesadaran dan mencapai tujuan komunikasi, apakah media tersebut cocok untuk RM karena sifatnya impersonal. Pendekatan yang lebih konvensional untuk menargetkan pelanggan yang dipilih termasuk metode portofolio pemasaran langsung seperti telemarketing, dan direct mail. Ketika produk cocok, penjualan langsung mungkin akan sukses. Tetapi jauh lebih baik jika marketer berdialog dengan pelanggan sasaran daripada berbicara dengan pelanggan di media massa.

Secara khusus, one-to-one (customization), one to many, many to many marketing memfasi-litasi upaya membangun hubungan pribadi dengan pelanggan39 sangat populer dikenal dalam direct marketing berbasis internet, penggunaan e-mail, dan media social lainnya. Saat ini bentuk pemasaran langsung muncul dengan menggunakan mouse, keyboard atau touch screen yang dilengkapi perintah untuk menerima pesan dari perusahaan menjadi metode yang sangat efektif menargetkan pelanggan untuk tujuan RM. Perusahaan dapat mengirim e-mail termasuk video, audio, dan web page ke ribuan orang setiap hari.

Tabel 4 menunjukkan bahwa e-mail merupakan pendekatan yang sangat efektif untuk biaya retensi pelanggan. Dengan biaya per 1,000, menunjukkan rasio Click Through Rate (CTR) lebih besar pada iklan banner dan e-mail yang dikirimkan ke pelanggan dapat menurunkan biaya per penjualan secara dramatis. Beberapa contoh berikut mungkin bisa membantu lebih jelas :

- Airlines, pada hari atau bulan tertentu mengirim e-mail ke pengguna setia untuk menawarkan tarif khusus.

- Toko penjualan buku offline mengumpulkan semua informasi pelanggan ke dalam database tunggal. Perusahaan kemudian menggunakan email yang disesuaikan dengan kecenderungan atau kepentingan pembaca.

\section{Issu Privasi}

Basis sistem RM yang tergantung pada database pelanggan dan analisis data untuk lebih efektif menargetkan komunikasi pemasaran dan kegiatan membangun hubungan. Ada trade off yang jelas antara kemampuan perusahaan untuk lebih memberikan produk dan jasa yang disesuaikan dengan jumlah informasi yang diperlukan untuk pengiriman. Terutama dengan popularitas media sosial, banyak konsumen dan kelompok advokasi pelanggan prihatin tentang jumlah informasi pribadi yang terkandung di dalam database dan bagaimana itu digunakan. ${ }^{40}$

Walaupun bukan isu baru, tetapi bagi marketer yang telah menggunakan (1) database selama bertahuntahun untuk keperluan analisis dan estimasi pengguna kendaraan bermotor, langganan majalah, transaksi kartu kredit, dan lainnya, (2) peningkatan e-mail langsung dan jumlah informasi yang sedang dikumpulkan melalui browsing web semakin lebih menonjol, dan (3) penayangan iklan, pemasaran langsung, referensi browsing web silang dan perilaku pembelian, marketer harus tetap menjaga privasi pelanggan dalam web marketing.

\section{KESIMPULAN}

Perubahan dalam lingkungan operasi bisnis serta perubahan sumber-sumber pendapatan, merupakan motif terkuat untuk menggunakan RM sebagai salah satu 
strategi pemasaran dalam memahami pelanggan dengan lebih baik dan memenuhi kebutuhan dan keinginan pelanggan lebih baik dari pesaing, serta membangun hambatan beralih ke perusahaan lain.

Suksesnya RM tergantung pada manfaat yang diperoleh pelanggan. Dampak RM terhadap loyalitas pelanggan tergantung pada nilai-nilai fungsional RM yang dapat dirasakan oleh pelanggan terhadap kualitas produk, posisi nilai dan harga, nilai tambah, kualitas hubungan, kualitas layanan, kepercayaan, komitmen, dan pembagian risiko.

Perusahaan yang paling efektif dalam menggunakan RM adalah perusahaan yang mampu mengkonversi pelanggan menjadi partner, menempatkan loyalitas sebagai strategi pertumbuhan. RM ditempatkan sebagai model berinteraksi dengan pelanggan, memberikan kualitas hubungan - layanan yang melampaui harapan pelanggan untuk menuai hasil (peningkatan pendapatan dan profitabilitas jangka panjang) yang benar-benar menarik, dan secara terus menurus memperluas segmen pelanggan yang paling menarik (profit).

Dalam Islam model RM ini dikenal dengan silaturahmi yang dijamin mampu menghasilkan manfaat ganda - menjadi salah satu pendekatan yang paling sukses. RM mengadopsi fokus pelanggan dan manfaat dari hubungan yang kuat dengan basis pelanggan utama termasuk peningkatan keuntungan melalui penurunan risiko, meningkatkan hubungan dan arah komunikasi, serta peningkatan kepuasan pelanggan yang mengarah pada retensi dan lebih banyak pelanggan yang setia. Power RM adalah kemampuannya (a) meningkatkan profitabilitas (b) membangun kemitraan (c) menarik perhatian pelanggan (d) membangun kepercayaan pelanggan, (e) mengurangi sensitivitas pelanggan terhadap harga, (f) mengurangi jumlah pembelotan pelanggan, (g) mengurangi biaya pemasaran dan kompleksitas operasional pemasaran.

Keberhasilan implementasi RM dalam membangun hubungan pertukaran dengan pelanggan dan merubah pelanggan baru menjadi pelanggan ulang yang berkelanjutan harus didukung oleh ketersediaan database pelanggan, analisis database pelanggan, seleksi pelanggan, spesifikasi target pelanggan, isu privasi, membangun hubungan, analisis nilai pelanggan, layanan pelanggan, teknologi pemasaran dan matrik keberhasilan sesuai dengan diferensiasi produk dan karakteristik segmentasi yang berbeda.

\section{DAFTAR PUSTAKA}

1. Benouakrim, H. and Kandoussi, F. E. 2013. Relationship Marketing: Literature Review. International Journal of Science and Research. Vol. 2 Issue 10, pp 148-152

2. Asmai Ishak, 2016. Seminar Teori Pamasaran: Kumpulan Bahan Kuliah Semester 2 Program Doktor
Ilmu Ekonomi. Yogyakarta: PPS Fakultas Ekonomi Universitas Islam Indonesia.

3. John G. S. 2011. Customer Relationship Marketing: Building Customer Relationship for Enduring Profits in a Wired Economy. Texas: Daystrom Court Dallas.

4. Palmatier, W. R. 2008. Relationship Marketing. Relationship Marketing. Cambridge, Massachusetts: Marketing Science Institute.

5. Filip, Alina and Voinea, Lelia. 2012. Understanding the Processes of Customer Acquisition, Customer Retention and Customer Relationship Development. International Journal of Economic Practices and Theories. Vol. 2, No. 2, pp 62-67

6. Frederick F. R. 2011. The Loyalty Effect. Cambridge. Marketing Assosiation: Harvard Business School Press.

7. Russell S. W. 2011. A Framework for Relationship Marketing. New York University. California Management Review, Summer (5) pp 1-26

8. Eisingerich, A. B. and Bell, S. J. 2007. Maintaining Customer Relationships in High Credence Services, Journal of Services Marketing, Vol 21 No 1, pp. 253262.

9. Mollah, A. S. 2014. The Impact of Relationship Marketing On Customer Loyalty. European Journal of Business and Management. Vol.6, No.3. pp 21 55

10. Jeff, S, H. 2010 "Information Privacy and Marketing. California Management Review, (2), pp. 8-33.

11. Audrey M, 2010. "Profiling the Chief Customer Officer," Customer Relationship Management, (1), pp.84-95

12. Lacey M, 2009. 'Customer advocacy and the impact of B2B loyalty programs. Journal of business \& industrial marketing, Vol 24 No 1, pp. 3-11.

13. Khalid K. Moenardy, K.K. Zainu, S. A, and Kumadji, S. 2016. The Effect of Service Quality and Relationship Marketing to Customer Value, Customer Satisfaction, Switching Cost, and Customer Retention. International Journal of Management and Administrative Sciences. Vol. 3, No. 04: pp 48-63

14. Roger J. Baran, Robert J. Galka. 2016. Customer Relationship Mana-gement The Foundation of Contem-porary Marketing Strategy. 2ed. UK: Routledge Taylor \& Francis Group Ltd

15. Brun, I. Rajaobelina, L and Line Ricard. 2016. Online Relationship Quality: Testing an Integrative and Comprehensive Model in the Banking Industry. Journal of Relationship Marketing. Vol. 15, - Issue 4. pp 219-246

16. Bricci, L. Fragata, A. and Antunes J. 2016. The Effects of Trust, Commitment and Satisfaction on Customer Loyalty in the Distribution Sector. Journal of Economics, Business and Mana-gement. Vol.4, No. 2: pp 173-177 
17. Shiaw-WT, Yi-C,C, Chia-H,H, Lin-L,T and Chih-H,T. 2011. An Empirical Study of Customer Relationship Implementation in Machine Industry. Journal of Industrial Management. (30) pp 1-16.

18. Zhang, J. Z. Watson G.F, Palmatier R.W and Rajiv P. D. 2016. Dynamic Relationship Marketing. Journal of Marketing. Vol 80 No 5, pp 53-75

19. Anastassova, L. 2013. Relationship Marketing: Customer LTV and Retention Strategies. Burgas University: Center for Business Studies.

20. Magasi, C. 2016. Customer Relationship Marketing and its Influence on Customer Retention: A Case of Commercial Banking Industry in Tanzania. Journal of Emerging Issues in Economics, Finance and Banking. Vol 5, Issue 1: pp 1756- 1775.

21. Lindgreen, Adam. 2004. The design, implementation and monitoring of a CRM programme: a case study. Marketing Intelligence \& Planning. Vol. 22 Issu 2. pp. 160 - 186

22. Payne, A. 2000. Relationship Marketing: The U.K. Perspective în Handbook of Relationship Marketing, Singapore: Sage Publications, Inc. pp. 39-67.

23. Zineldin and Philipson, 2007. 'Kotler and Borden are not dead: myth of relationship marketing and truth of the 4Ps, Journal of consumer marketing. Vol 24 No 4. pp. 229-241.

24. Bennett, R. and Barkensjo, A. 2005. 'Relationship quality, relationship marketing, and client perceptions of the levels of service quality of charitable organisations', International journal of service industrial management. Vol 16 No 1. pp. 81 106.

25. Stanley A. Brown, 2011. Customer Relationship: A Strategic Imperative in the World of E-Business: Canada: John Wiley and Sons. Ltd

26. Ndubisi, N. O. 2007. Relationship Marketing and Customer Loyalty'. Marketing Intelligence \& Planning, Vol 25 No 1. pp. 98-106.

27. Hatem E, G. 2011. The effect of marketing on the marketing performance: Bradford University School of Management. Edamba Summer Academy: (16) pp 2-13

28. Werner J. R and Kumar, V. 2009. "On the Profitability of Long-Life Customers in a Noncontractual Setting: Journal of Marketing, (10) pp.17-35.

29. Kumar, Batista, and Maull: 2011. The Impact of Operations Performance on Customer Loyalty. Journal of Service Science. Vol 3 No 2. pp. 158-171.
30. Chen, Z. X., Shi, Y. and Dong, D. 2008. 'An empirical study of relationship quality in a service setting, Marketing intelligence \& planning, Vol 26 No 1. pp. 11-25.

31. Athanasopoulou, P. 2009. 'Relationship quality: a critical literature review and research agenda', European journal of marketing. Vol 43 No 5. pp. 583-610.

32. Yuping, L. \& Rong, Y. 2011. Competing loyalty programs: impact of market saturation, market share, and category expandability. Journal of Marketing. 73 pp 93-108.

33. Vutete, Clever. 2015. Modelling Share of Mind and Share of Heart As Contemporary Measures of Competitive Success. Journal of Business and Management. Vol 17, Issue 10: pp 1-8

34. Kehinde, O. J. Adegbuyi, A. Omotayo A. A and Tairat B.T. 2016. Relationship Marketing: The Effective Sales Performance In The Banking Industry. Journal Research of Management. Vol. 4. No. 2 pp 2-12

35. Feng Bai, Feng and Qin, Yafeng, 2016. The Implementation of Rlationship Marketing and CRM: How to Become a Customer - Focused Oganization. Journal of Business \& Economic Policy. Vol. 3. No. 2. pp 112-124

36. Eggert U, 2006. 'Relationship value and relationship quality: broadening the network of business-tobusiness relationships', European journal of marketing. Vol 40 No 3. pp. 311-327.

37. Rodriguez M., Paredes F., Yi G. 2016.Towards Future Customer Experience: Trends and Innovation in Retail. Foresight and STI Governance. Vol. 10 No 3. pp. 18-28.

38. Venkatesan R and Kumar V. 2004. A Customer Lifetime Value Framework for Customer Selection and Resource Allocation Strategy. Journal of Marketing. Vol. 68 No 10. pp 106-125

39. Berger. Paul D. and Nasr. Nada I. 2012. Customer Lifetime Value: Marketing Models And Applications. Journal of Interactive Marketing. Vol 12. No 1. pp 1730

40. Pelteret, M. \& Ophoff, J. 2016. A review of information privacy and its importance to consumers and organizations. International Journal Informing Science of an Emerging Transdiscipline. (19). pp 277-301

Tabel 4. Biaya Akuisis dan Retensi Pelanggan

\begin{tabular}{|l|c|c|c|c|c|}
\hline \multirow{2}{*}{ Jenis } & \multicolumn{3}{|c|}{ Customer Acquisition } & \multicolumn{2}{c|}{ Customer Retention } \\
\cline { 2 - 5 } & direct mail & $\begin{array}{c}\text { banner } \\
\text { advertising }\end{array}$ & $\begin{array}{c}\text { email to } \\
\text { rented }\end{array}$ & direct mail & e-mail to "house" \\
\hline Cost per 1,000 & $\$ 850$ & $\$ 16$ & $\$ 200$ & $\$ 686$ & $\$ 5$ \\
\hline Click Through Rate & N/A & $0.80 \%$ & $3.50 \%$ & $\mathrm{~N} / \mathrm{A}$ & $10 \%$ \\
\hline Purchase Rate & $1.20 \%$ & $2.00 \%$ & $2.00 \%$ & $3.90 \%$ & $2.50 \%$ \\
\hline
\end{tabular}

